
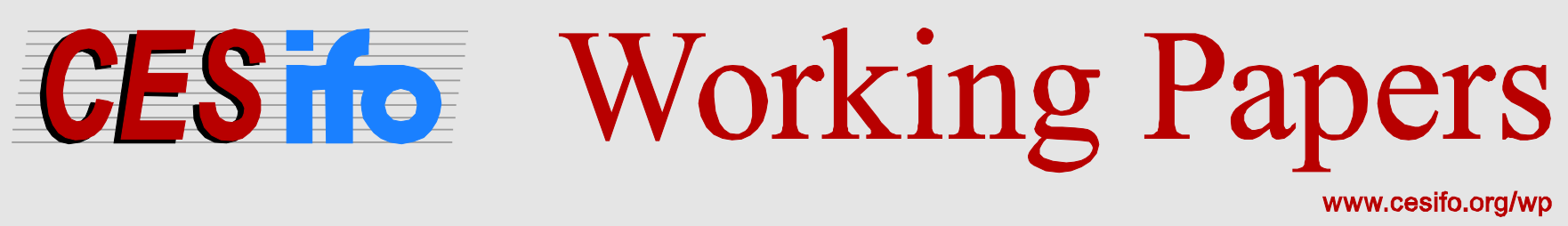

\title{
Central Banking and Crisis Management from the Perspective of Austrian Business Cycle Theory
}

\author{
Gunther Schnabl
}

\author{
CESIFO WORKING PAPER NO. 6179 \\ CATEgORY 7: MONETARy POLICY AND InTERNATIONAL FinANCE \\ NOVEMBER 2016
}
An electronic version of the paper may be downloaded
- from the SSRN website:
- from the RePEc website:
- from the CESifo website:
www.SSRN.com
www.RePEc.org
www.CESifo-group.org/wp




\title{
Central Banking and Crisis Management from the Perspective of Austrian Business Cycle Theory
}

\begin{abstract}
The paper analyses the evolvement and effects of central bank crisis management since the mid 1980s based on a Hayek-Mises-Wicksell overinvestment framework. It is shown that, given that the traditional transmission mechanism between monetary policy and consumer price inflation has collapsed, asymmetric monetary policy crisis management implies a convergence of interest rates towards zero and a gradual expansion of central bank balance sheets. From a Hayek-MisesWicksell perspective asymmetric central bank crisis management has contributed to financial market bubbles, decreasing marginal efficiency of investment, increasing income inequality and declining growth dynamics. The economic policy implication is a slow but decisive exit from ultra-expansionary monetary policies.
\end{abstract}

JEL-Codes: E520, E580, F420, E630.

Keywords: Hayek, Mises, Wicksell, monetary overinvestment theory, asymmetric monetary policy, financial crisis, Goodhart's Law, marginal productivity of investment, secular stagnation.

\author{
Gunther Schnabl \\ University of Leipzig \\ Grimmaische Straße 12 \\ Germany-04109 Leipzig \\ schnabl@wifa.uni-leipzig.de
}

9 Nov. 2016

I thank Andreas Hoffmann and an anonymous referee for helpful comments and the Friedrich August von Hayek-Foundation and the Jackstädt Foundation for financial support. I thank Hannes Böhm excellent research assistance. 
At the latest with the US subprime crisis and the European financial and debt crisis, the central banks of the large industrialized countries are widely understood as key players in (financial) crisis management. With large financial institutions tumbling, threatening to trigger a melt-down in the global financial system, decisive interest rate cuts and ample liquidity provisions have become standard tools to ensure financial and economic stability. Since the mid 1980s, the asymmetric nature of monetary policy crisis management - i.e. a stronger monetary expansion during crisis than monetary tightening during the recovery after the boom - have led to a gradual decline of interest rates towards zero and an inflation of central bank balance sheets.

Because the structural decline of interest rates has been accompanied by low consumer price inflation, monetary policy crisis management was regarded for a long time as an outstanding success. With improved communication skills being assumed to ensure low inflation (Woodford 2003), interest rates as operational target (or later the size of the central bank balance sheet) became popular tools to achieve additional goals such financial stability and growth. The outbreak of the US subprime crisis and the European financial and debt crisis have destroyed, however, the illusion of the Great Moderation (Bernanke 2005). Now, the structural decline of the nominal and real interest rates is interpreted as response to a structural decline of growth dynamics, which are linked to a saving glut of ageing societies, declining (marginal efficiency of) investment and (exogenously) increasing income inequality (Gordon 2012, Summers 2014, von Weizsäcker 2014).

The result is a declining - what Summers (2014) calls - natural interest rate, which involves an increasing probability of financial market bubbles, while product markets remain in equilibrium. Similarly, Laubach and Williams (2015) suggest that (in the US) the fall in trend GDP growth rates triggered a decline in the natural rate of interest, which implies that the gradual interest rate cuts of the Fed are an inevitable response to the secular stagnation. This explanation approach is in line with the literature, which sees financial crises as result of random or exogenous shocks, amplified by the irrationality of human action and therefore sees discretionary policy intervention as indispensable to stabilize inherently instable markets (Keynes 1936, De Grauwe 2010). Monetary policy has increasingly become the pivotal instrument of crisis management, because with high levels of government debt and growing 
dimension of crises, fiscal crisis management has reached its limits.

In contrast to the Keynesian views, monetary policy crisis management is discussed here from the point of view of the monetary overinvestment theories by Mises (1912) and Hayek (1929, 1931), which see too loose monetary policies as the origin of structural distortions and crises. This view is line with assessments based on the Taylor (1993) Rule that suggest that too expansionary monetary policies during the 2000s sowed the seeds for financial exuberance and therefore the current crisis (see Taylor 2007, Jorda et al. 2015, Adrian and Shin (2008), Brunnermeier and Schnabel (2014) as well as Hoffmann and Schnabl (2008, 2011, 2016a)). The approach is in many aspects similar to Borio's (2014) perception of the financial cycle, but takes a stronger focus on the role of central banks for crisis management. They extend Borio (2014) to the possible role of central banks for the emergence of crisis.

\section{Asymmetric Monetary Policy Patterns}

To model the central bank crisis management emerging since the mid 1980s a Wicksell (1898), Mises (1912) and Hayek (1929, 1931) based monetary overinvestment theory framework is used. This allows to understand asymmetric monetary policy crisis management patterns since the mid 1980s. ${ }^{1}$ Whereas Borio (2014) takes the empirical observation of financial cycles as a starting points and matches it with the currently dominating business cycle theories, we take the seminal Austrian business cycle theory as starting points and match it with the observed stylized facts occurring in financial markets.

\subsection{An Austrian Business Cycle Framework}

Based on the business cycle theories of Wicksell, Mises and Hayek four types of interest rates can be distinguished: First, the internal interest rate $i_{i}$ which reflects the (expected) returns of (planned) investment projects. Second, Wicksell's (1898) natural interest rate $i_{n}$ is the interest rate that balances the supply (saving) and demand (investment) of capital (and thereby does neither cause inflation nor deflation). Third, the central bank interest rate $i_{c b}$ is the policy interest rate set by the central bank. It represents the interest rate which commercial banks are

\footnotetext{
1 The monetary overinvestment theories of Mises (1912) and Hayek (1929; 1931) fulfil the requirements for a theory of financial cycles as formulated by Borio (2014: 186-187) as follows: (1) The financial boom not only precedes the bust, it also causes the bust. (2) There is a capital overhang (i.e. overinvestment), which is related to debt overhang (unsustainable credit growth). (3) There is a notion of a sustainable level of output, with the deviation of realized output from sustainable output being related to monetary conditions.
} 
charged by the central bank for refinancing operations. Fourth, the capital market interest rate $i_{c}$ is defined as the interest rate set by the private banking (financial) sector for credit provided to private enterprises. For simplification it is assumed that under normal conditions the capital market interest rate equals the policy interest rate (see Hoffmann and Schnabl 2011).

Wicksell (1898) and Hayek $(1929,1931)$ have different concepts of the natural interest rate. According to Wicksell (1898), the deviation of the central bank interest rate (and the capital market interest rate) from the natural rate of interest (which guarantees goods market equilibrium) disturbs the equilibrium between ex-ante saving and investment plans, bringing about inflationary $(\mathrm{I}>\mathrm{S})$ or deflationary processes $(\mathrm{S}>\mathrm{I}) .^{2}$ During an inflationary credit boom, the supply of goods cannot satisfy the additional demand for goods at given prices. Therefore, Wicksell's natural rate of interest is the interest rate at which inflation is zero (or at the target level). In contrast to Say, in Wicksell's framework money is not neutral, but additional money supply affects decisions of economic agents triggering additional credit provision. ${ }^{3}$ Although he does not directly refer to overinvestment Wicksell (1898) stresses (in contrast to Woodford (2003)) the role of the production structure for the transmission of monetary policy to inflation. $^{4}$

Building on Wicksell (1898), Mises (1912) and Hayek (1929, 1931) aimed to explain business cycles caused by the deviation of the central bank interest rate (capital market interest rate) from the natural rate of interest. They attribute the main role in the creation of cycles to credit

2 Therefore, the theory of Wicksell can be seen as the foundation of inflation targeting frameworks. If the central bank adjusts successfully the central bank interest rate to the natural interest rate, the inflation rate will be zero.

3 "In other words, the real cause of the rise in prices is to be looked for, not in the expansion of the note issue as such, but in the provision by the bank of easier credit, which is itself the cause of the expansion." (Wicksell 1936: 87).

4 "It follows obviously that unless the fall in the rate of discount is neutralised by simultaneous changes elsewhere, it must, when it has persisted long enough to exert a depressing influence on long-term rates of interest, provide a stimulus to trade and production, and alter the relation between supply and demand of goods and productive services in such a way as necessarily to bring about a rise in all prices." (Wicksell 1936: 89).

"Now let us suppose that the banks and other lenders of money lend at a different rate of interest, either lower or higher, from that which corresponds to the current value of the natural rate of interest on capital. The economic equilibrium of the system is ipso facto disturbed. If prices remain unchanged, entrepreneurs will in the first instance obtain a surplus profit (at the cost of the capitalists) over and above their real entrepreneur profit or wage. This will continue to accrue so long as the rate of interest remains in the same relative position. They will inevitably be induced to extend their businesses in order to exploit to the maximum extent the favourable turn of events. And the number of people becoming entrepreneurs will be abnormally increased. As a consequence, the demand for services, raw materials, and goods in general will be increased, and the prices of commodities must rise." (Wicksell 1936: 105) 
creation triggered by the central bank and the private banking sector. Hayek $(1929,1931)$ emphasized the importance of the intertemporal misalignments of plans of producers and consumers to derive mal- or overinvestment ${ }^{5}$ as mismatch between the production structure and consumer preferences. The natural interest rate is the interest rate that aligns saving and consumption preferences with the production structure over time. A fall in the central bank interest rate (capital market interest rate) below the natural interest rate causes a cumulative inflationary process, creating distortions in the production structure that later make an adjustment necessary (unless the central bank keeps on inflating credit at an ever-increasing pace and artificially prolongs the credit boom).

\section{Figure 1: Equilibrium}

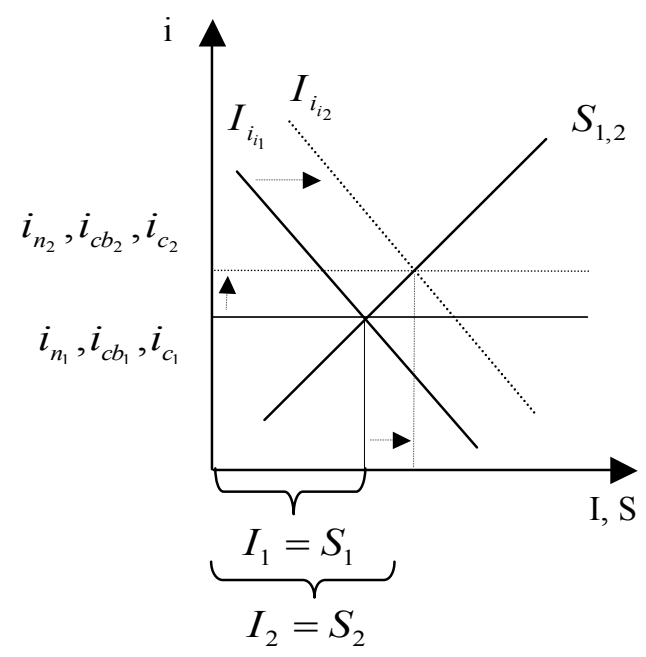

An economy is in equilibrium when the natural rate of interest equals the central bank interest rate, i.e. planned savings equal investment. In the view of Mises (1912) and Hayek (1929, 1931) an economic upswing starts when positive expectations - for instance due to an important innovation - raise the internal interest rate of investment, bringing about a rise in investment demand at given interest rates. ${ }^{6}$ In Figure 1 this corresponds to a right shift of the

5 Mises (1912) and Hayek (1929) used in German the word „Überinvestition“ (in English: overinvestment). In the English literature on Austria business cycle theory the term „malinvestment” is more common.

6 Wicksell (1936: 67) saw innovation, i.e. a real factor, as the main trigger of business cycles: "It is in the nature of things that new, great discoveries and inventions must occur sporadically, and that the resulting increase in output cannot take the form of an evenly growing stream like population growth and the increase in consumption demand. (...) For my part, until I am shown something better, it is in this that I discern the real source of economic fluctuations and crises, which, in their present form, belong entirely to modern times." Nevertheless, also monetary elements can be found (Wicksell 1936: 232): "But above all, new inventions, of whatever kind they be, almost always require for their materialization a great deal of preparatory labour, creation of new facilities, etc., in a word, they require capital (...) But a crisis can hardly 
investment curve from $I_{i_{i_{1}}}$ to $I_{i_{i_{2}}}$. The natural rate of interest rises along from $i_{n_{1}}$ to $i_{n_{2}}$. Credit demand in the economy rises. If the central bank increases the policy rate from $i_{c b_{1}}$ to $i_{c b_{2}}$, assuming a perfect interest rate transmission to credit markets, planned saving and investment in the economy will stay in equilibrium $\left(S_{2}=I_{2}\right)$. If, however, the central bank does not raise the policy interest rate, $\left(i_{n_{1}}=i_{c b_{1}}=i_{c b_{2}}<i_{n_{2}}\right)$ as shown in the left panel of Figure 2, relatively low interest rates will give rise to an unsustainable overinvestment boom. Holding policy rates too low (for too long) in the following will be referred to as monetary policy mistake of type 1.

\section{Figure 2: Boom and Bust}
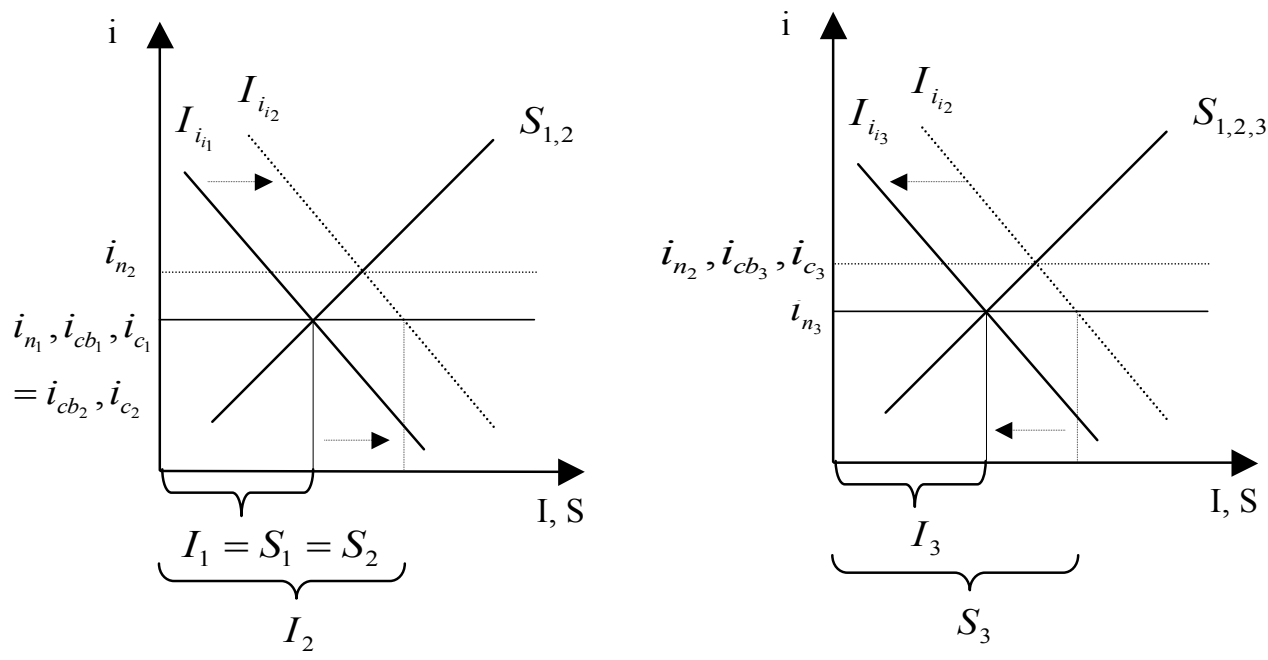

To market participants a rise in credit to the private sector at constant interest rates signals that saving activity of households increased. Additional investment projects aim to satisfy the expected rise in future consumption. As planned household saving does not increase, an unsustainable disequilibrium between ex-ante saving and investment $S_{2}<I_{2}$ at $i_{c_{2}}<i_{n_{2}}$ arises. In the following, additional investments of some enterprises trigger additional investments of other enterprises (cumulative upward process). As soon as capacity limits are reached and unemployment is low, wages and prices rise.

be avoided if new ventures have been started on a scale that gradually makes the available capital insufficient. And this crisis is reinforced by the psychological factors which exert an influence on the money and credit market in such circumstances-the excessive lack of confidence which replaces the all too widespread reliance on willingness to extend credit, and so on." 
At first, rising prices signal additional profits and therefore trigger a further increase in investment. There may be spill-overs to financial markets. Increases in expected profits of companies are typically associated with rising stock prices. Given relatively low interest rates on deposits, shares are an attractive investment class. When stock prices move upward, trendfollowers will provide extra momentum such that "the symptoms of prosperity themselves finally become [...] a factor of prosperity" (Schumpeter 1912, p. 226). ${ }^{7}$ Consumption is fueled by rising stock prices via the wealth channel, which leads, with a lag, to an increasing price level.

The boom turns into bust, when the central bank increases the central bank interest rate to slow down inflation (Mises 1912; Hayek 1929; 1931; 1937). Then, investment projects with an internal interest rate below the risen natural interest rate turn out to be unprofitable. The fall in investment of some firms will depress investment of other firms as expected returns fall. When stock (and other asset prices) burst, balance sheets of firms and banks worsen, bringing about further disinvestment (cumulative downward process). The investment curve shifts back from $I_{i_{i_{2}}}$ to $I_{i_{i 3}}$ (right panel of Figure 2). The natural interest rate falls to $\mathrm{n}_{3}$. Wages fall and unemployment rises.

In this situation, the central bank should cut the central bank interest rate to contain the downward-spiral. Yet, the central bank interest rate is kept too high. Figure 2 shows that when the policy interest rate is above the natural interest rate $\left(i_{c b_{3}}=i_{c_{3}}>i_{n_{3}}\right)$, credit supply is restricted further such that ex-ante saving is higher than investment $\left(S_{3}>I_{3}\right)$. This aggravates the downturn beyond what would be necessary to remove the structural distortions, which have been induced by type 1 monetary policy mistakes. Based on the monetary overinvestment theories, we consider holding policy interest rates above the natural interest rate during the downturn as monetary policy mistake of type 2 .

\subsection{Asymmetric Monetary Policy Crisis Management Patterns}

From the point of view of Mises (1912) and Hayek (1929) monetary policy crisis management is a failure, if interest rates are held too high (above the new natural interest rate $\mathrm{i}_{\mathrm{n} 3}$ ) during the crisis (what corresponds to a type 2 monetary policy mistake). In line with this

\footnotetext{
7 Borio (2014: 183-186) discusses the link between real and financial cycles. He does find a direct link.
} 
notion Friedman and Schwartz (1963) as well as Bernanke (1995) argued that the US Fed had kept interest rates too tight during the early years of the 1930s world economic crisis, what they argue to have aggravated the crisis. ${ }^{8}$ Similarly, the Bank of Japan was blamed to have kept the interest rate too high in the early years after the bursting of the Japanese bubble economy in December 1989 (Bernanke 2000, Posen 2000).

\section{Figure 3: G3 Short-Term Interest Rates}

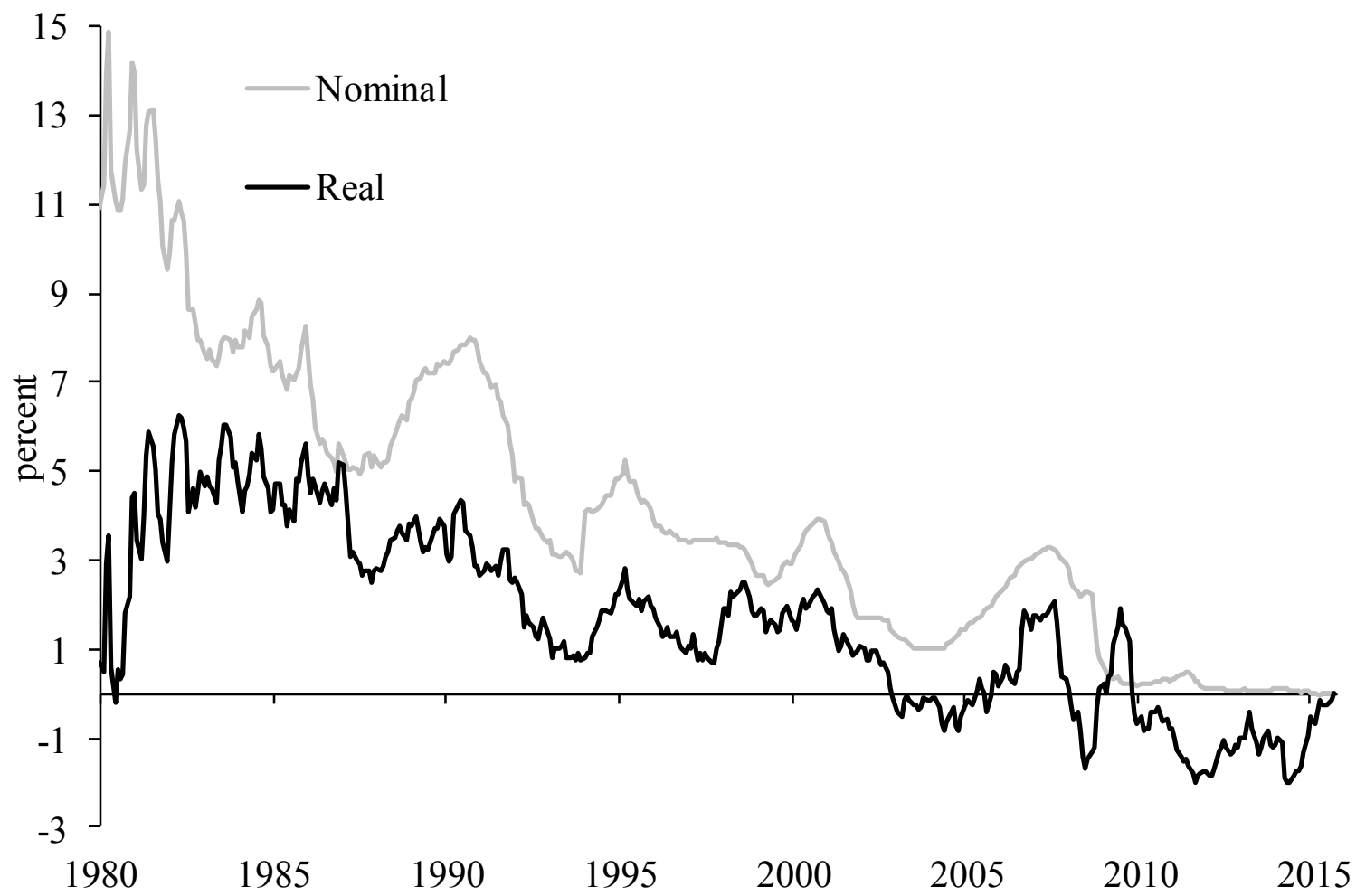

Source: International Monetary Fund (IMF), via Datastream, 2016. G3=US, Japan and Germany (up to 1998)/euro area; arithmetic averages.

Given the lessons drawn by Bernanke (and others) from the world economic crisis, starting from the late 1980s in the US an asymmetric central bank crisis management pattern emerged. With crisis more and more originating in financial markets and with inflation remaining at historically low levels, monetary policy was increasingly used as a tool of crisis management. When prices in some financial market segments sharply declined, the Federal Reserve under

8 "Let me end my talk by abusing slightly my status as an official representative of the Federal Reserve. I would like to say to Milton and Anna: Regarding the Great Depression. You're right, we did it. We're very sorry. But thanks to you, we won't do it again." (Bernanke 2002). In their classic study of U.S. monetary history, Friedman and Schwartz (1963) presented a monetarist interpretation of these observations, arguing that the main lines of causation ran from monetary contraction-the result of poor policy-making and continuing crisis in the banking system--to declining prices and output." (Bernanke 1995, 3) 
the chairmen Alan Greenspan and Ben Bernanke cut interest rates decisively to ensure financial market stability by preventing type 2 monetary policy mistakes.

In contrast, during the recoveries after the crisis the Federal Reserve and increasingly other central banks such as the Bank of Japan and the European Central Bank tended to keep interest rates low in order to not endanger the economic recovery. Because interest rate cuts and central bank balance sheet expansions were less and less reflected in consumer price inflation (see section 3.1), central banks could hold interest rates very low for rather long during periods of economic recovery without interfering with their inflation targets. This asymmetric policy approach was reflected in the 'Jackson Hole consensus', where US central bankers claimed that central banks do not have sufficient information to spot financial market bubbles, but should react swiftly in times of financial turmoil (Blinder and Reis 2005).

Figure 4: G3 Central Bank Assets as Shares of Gross Domestic Product

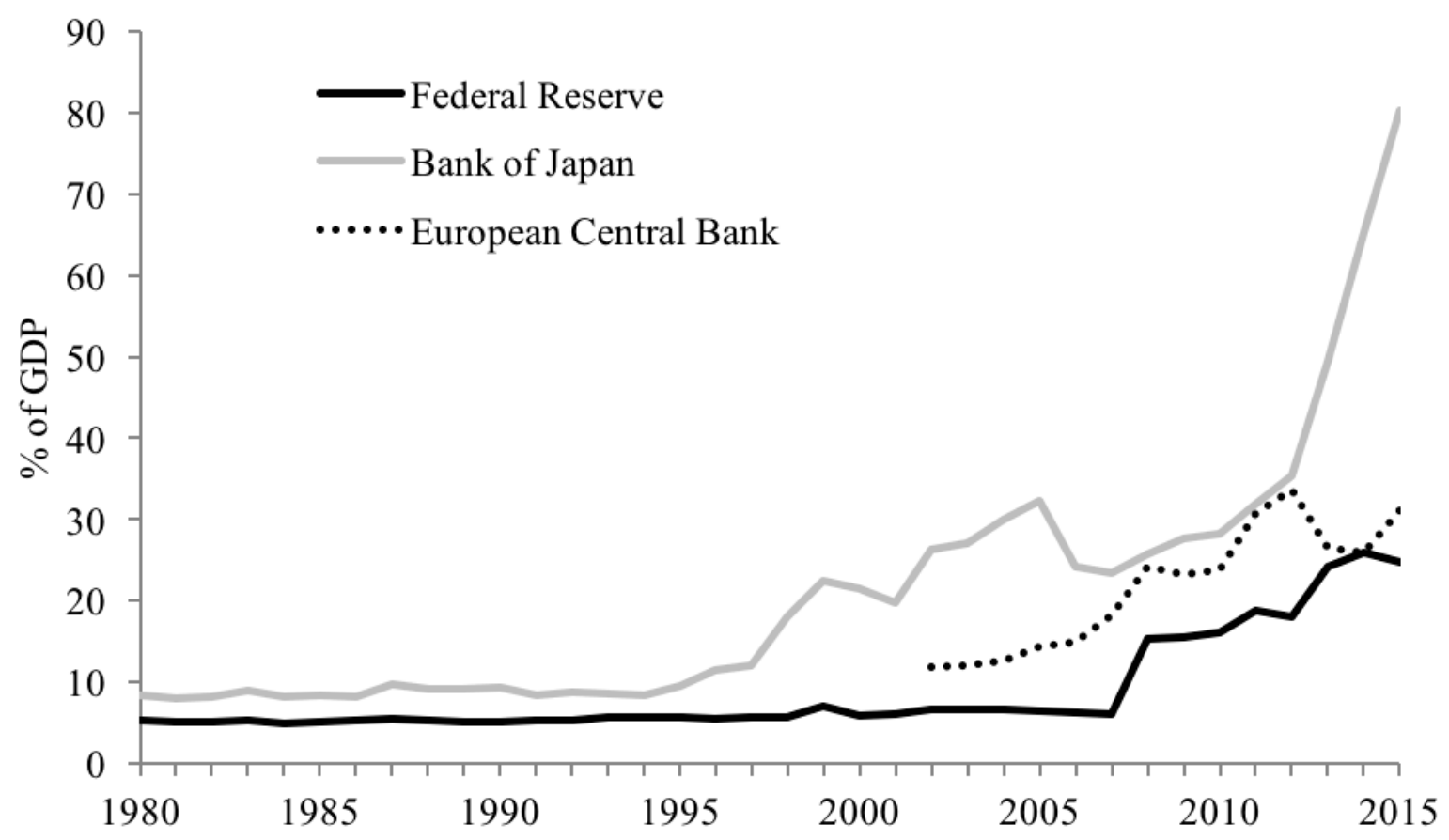

Sources: European Central Bank and Eurostat, Bureau of Economic Analysis (BEA), Cabinet Office (Japan), IMF.

As this approach to central bank crisis management seems to have caused new booms in financial markets (see section 3.2), central banks may have tended to transform monetary policy mistakes of type 2 into monetary policy mistakes of type 1. By cutting interest rate in the face of crisis below the natural interest rate and by keeping interest rates during the 
recovery below the natural interest rate, short-term nominal interest rates were depressed - in cycles - down to zero as shown in Figure 3. With the zero interest rates being reached, unconventional monetary policies became mainly based on forward guidance that short-term and long-term interest rates would remain low. The continuing downward trend of long-term interest rates was ensured by the extensive government bond purchases of central banks, which inflated or shall inflate central bank balance sheets at growing speeds (Figure 4). The controversial discussions on the US Fed's tapering and the long-delayed increase in interest rates by the Federal Reserve (for the first time after nine years in 2015) and other large central banks, signal that an exit from zero interest rate policies and balance sheet expansion is a difficult endeavor.

\section{Asymmetric Effects of Monetary Policy Crisis Management on Consumer and Asset Prices}

Monetary policy as a tool of crisis management had since the mid 1980s several benefits. Given that crises increasingly materialized as financial crises, central banks could respond fast, when the potential collapse of systemic financial institutions threatened to trigger ostensibly uncontrollable chain reactions. The large and further growing scales of rescue measures could be easily financed via base money creation. Governments remained (widely) spared from having to pass increasing costs of crisis management through the parliaments. Whereas the fiscal costs of crisis management would have become visible in form of growing government debt, tax hikes or dire expenditure cuts, the costs of monetary crisis management are more difficult to trace and therefore more difficult to associate with policy mistakes (see section 4).

In particular, gradual interest rate cuts towards zero and unprecedented central bank balance sheet expansions (Figure 3 and 4) went along with historically low consumer price inflation (Figure 5), which kept monetary policy crisis management in line with the widely used inflation targeting regimes. Instead, monetary policy crisis management became increasingly visible in asset markets, which central banks continued to regard to be outside their responsibility. 


\section{Figure 5: Inflation Rates in G3 Countries}

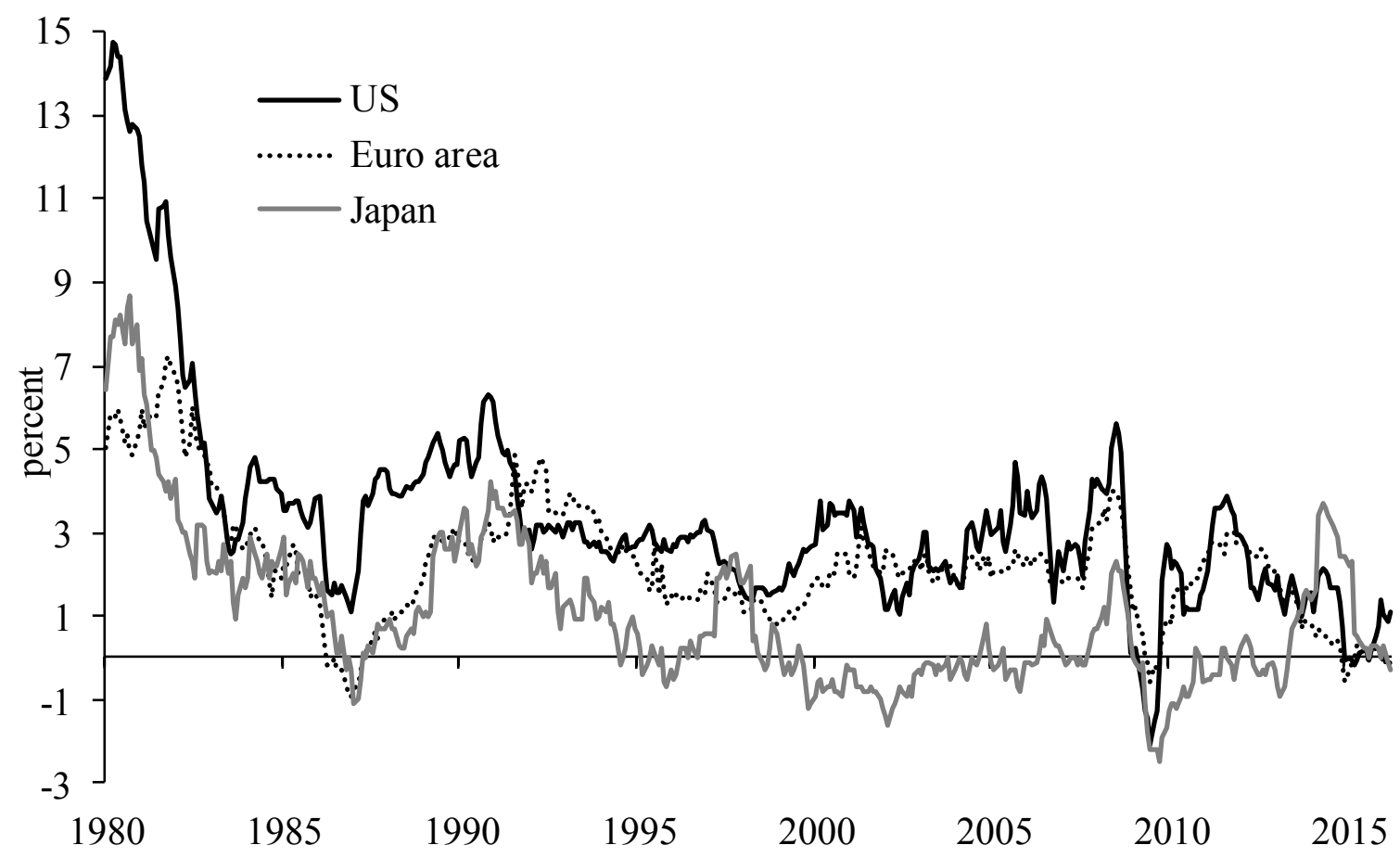

Sources: Thomson Reuters, Japanese Ministry of Internal Affairs \& Communication, Bureau of Labor Statistics (BLS), Eurostat.

\subsection{Monetary Policy Crisis Management and Low Inflation}

At the end of the 1970s, the notion that monetary policy could reduce unemployment via surprise inflation (Phillips curve effect) had proven to be misleading. Lucas (1976) showed that rational private agents adjust their behavior in a dynamic game situation to discretionary policy interventions. Central banks became regarded to be able to generate short-term employment effects, but at the cost of rising uncertainty and - in the long term - lower investment and growth. This paved the way for rules in monetary policy making, which intended to isolate central banks from the short-term goals of policy makers such as crisis management. ${ }^{9}$ Wicksell (1898) had pioneered the idea that the interest rate should be used to stabilize inflation.

Friedman (1970) launched the idea of a rule for money supply growth, which he proposed to be calculated based on macroeconomic fundamentals and financial factors, targeting a

\footnotetext{
9 New Zealand was the first country to introduce an inflation targeting framework in 1989.
} 
specific level or range of inflation. ${ }^{10}$ Kydland and Prescott (1977) designed for democracies easy institutionalized rules, which should be difficult to reverse. This put the stage for monetary policy rules, which were framed by operative, institutional and financial central bank independence (Barro and Gordon 1983). The German Bundesbank created a corridor for money supply growth to achieve low inflation. After the link between money supply and inflation had proven as instable, inflation targeting combined with central bank independence became the widely accepted frameworks to control consumer price inflation (Taylor 1993). A model generation was born, where a specific inflation target could be achieved by decisive central bank communication without targeting monetary aggregates (Woodford 2003). ${ }^{11}$

The coincidence of historically low inflation rates in most industrial countries with the introduction of inflation targeting frameworks in a growing number of industrialized countries and emerging market economies was seen as a proof for the success of inflation targeting. Bernanke (2004) created the notion of the Great Moderation: central banks seemed to able to keep inflation low via clear communication of their inflation targets, while at the same time being able to use interest rates and base money supply as tools of crisis management. The US subprime crisis put a harsh end to the Great Moderation, revealing that the establishment of inflation targeting frameworks in a large number of countries had triggered a new round of game situation: Whereas private agents seem to have adjusted their behavior to the establishment of the inflation targeting rules to maximize their personal utilities, central bankers adhered to their increasingly ineffective targets.

Goodhart $(1975 ; 5)$ argued that "any observed statistical regularity will tend to collapse once pressure is placed upon it for control purposes." In this context the underlying statistical regularity can be the positive relationship between monetary base (money supply) and consumer price inflation as assumed by the quantity equation. Assuming a stable negative relationship between monetary base and interest rate ${ }^{12}$, the Taylor rule and other inflation

10 Friedman $(1970,24)$ argued that „Inflation is always and everywhere a monetary phenomenon in the sense that it is and can be produced only by a more rapid increase in the quantity of money than in output."

11 Monetary policy according to Woodford (2003) is similar to Wicksell (1898) in that interest rates are used to control inflation. Woodford (2003) calls his models "neo-Wicksellian." However, one considerable difference is that the model framework of Woodford (2003) does not require monetary aggregates, whereas according to Wicksell (1898) these play an important role in the transmission of changes in interest rates to inflation via credit creation.

The central banks did usually not change directly the monetary base to influence inflation as often assumed in text books. Moreover, they used the interest rate as an intermediate target of monetary policy making, which has implications on the credit creation of the banking system and therefore on the base money held by commercial banks at the central bank. Base money can be decomposed in several components, out of which 
targets are based on the quantity equation. This is best formulated in the derivation of the $2 \%$ inflation target and the reference value for the money supply growth of the European Central Bank. ${ }^{13}$ Indeed, the relationship between money supply or the monetary base and consumer price inflation became increasingly empirically to trace (see Gertler and Hofmann 2016). Whereas central banks gradually cut interest rates towards zero and gradually expanded their balance sheets far beyond real GDP growth, inflation rates fell to historically low levels (Figure 3, 4, 5).

Figure 6 shows based on the quantity equation the collapse of the link between base money (as a proxy for monetary policy) and consumer price inflation. It shows rolling regressions of inflation on base money growth based on ten-year backward-looking windows. ${ }^{14}$ Sufficiently long time series are available for the US and Japan. In the 1970s the assumed positive relationship between the base money growth and consumer price inflation is confirmed for both US and Japan. The respective coefficient is positive and statistically significant at the common levels. During the 1980 s the positive relationship vanishes and is no longer detectable starting from the 1990s. By contrast, a (partially statistically significant) negative relationship seems to have emerged since the turn of the millennium. The more the Fed and the Bank of Japan expanded their balance sheets to push up inflation, the lower inflation was.

Assuming that monetary policy crisis management has become increasingly visible in asset markets (see section 3.2.), the effect of monetary expansion on consumer price inflation is delayed as it takes a detour via asset markets. If unconventional monetary policy causes a rise in asset prices (instead of consumer prices), wealth effects will still stimulate demand for

only open market operations are directly controlled by the central bank (see Disyatat 2008). Autonomous factors as important components of base money such as standing facilities or the demand for coins and notes in circulation can not be directly influenced by the central bank. Therefore, the reserve holdings of the commercial banks at the central bank tend to be in the short-term independent from the interest rate decisions of the central bank. However, in the medium term central banks influence the monetary base via the impact of its interest rate decisions on economic activity. If the central bank cuts (lifts) interest rates, under normal conditions, the commercial banks' credit provision to the private sector will increase (fall) and therefore the demand for base money will grow (fall) as well. Since money market rates have reached the zero bound in most industrialized countries, the monetary bases (or the size of the central bank balance sheets) have become the direct instrument of monetary policy making.

13 The European Central Bank assumed the average real growth rate of the euro area to be $2 \%$ and the change in the velocity of money to be $0.5 \%$ per year. Given an inflation target of $2 \%$, this implied a reference value for money supply growth of $4.5 \%$. After the turn of the millennium up to the European financial and debt crisis the reference value for money supply growth was mostly missed by far, while the inflation target of close to $2 \%$ was mainly achieved. For this reason and because the connection between money supply and inflation had proved to be empirically hardly traceable, money supply growth as a reference for monetary policy decisions was stepwise discarded and moved from the first to the second pillar of the European Central Bank's monetary policy strategy in 2003.

14 The velocity of money is assumed to be constant. 
consumer goods as some people feel richer. However, this increase in consumer prices is delayed, what implies a growing time lag before the inflation target is hurt following a monetary expansion.

If redistributive effects cause a rise in demand for mainly luxury goods (see section 4.3), which are not included or underrepresented in the predefined consumer baskets, then only substitution effects between the various product groups can result in more inflation. The monetary policy transmission towards higher inflation is delayed even further. The relationship between the monetary base and inflation can be postponed to an extent that inflation will not rise noticeably until a considerable bubble has already built up in one or another segment of national or international asset markets. If the central bank then lifts its interest rate in an effort to curb the looming inflation, the bubble will burst. The financial crisis dampens inflation again.

The now increasingly unchallenged insight that monetary policy has become increasingly visible in asset markets (see section 3.2), may hinge on a structural change in the transmission of monetary policy. The financial sector as a group of rational economic agents - which has a core role in the transmission of monetary policy - may have changed in the spirit of Lucas (1976) its behavior in response to the introduction of the monetary policy rules. In the case of a monetary expansion additional liquidity is provided by the central bank to a set of financial institutions, which decide as so-called primary dealers about the allocation of the additional funds. ${ }^{15}$ The traditional perception of the monetary policy is that the additional liquidity is transferred - supported by lower interest rates - in form of additional credit to households and enterprises. A growing credit volume is linked to increasing profits of commercial banks. Additional consumer credits lead to additional demand for consumer goods and - given full capacities or rigid supply - to rising prices.

If enterprises anticipate the growing demand for consumer goods, they will invest more to expand their production capacities. For this purpose, the resources have to be shifted first from the consumption goods sector to the investment goods sector, what implies less supply of consumer goods and therefore further rising prices. If households expect growing inflation (and free capacities on the labor market are depleted) trade unions will bid for higher wages. Higher wages will trigger higher prices. Once inflation rises (or is anticipated to rise), the

\footnotetext{
${ }^{15}$ This effect is circumvented in case of helicopter money, which is directly distributed among households.
} 
inflation targeting framework will force the central bank to tighten money supply to tame inflation. The resulting increase in interest rates will force the commercial banks to tighten credit supply. Investment and consumption will slow down, which reduces demand on labor markets and therefore puts a ceiling on wage and price pressure. During the resulting downturn the profits of financial institutions will decline as credit volumes shrink and some debtors default.

Figure 6: Rolling Coefficients for the Effect of the Monetary Base on Inflation

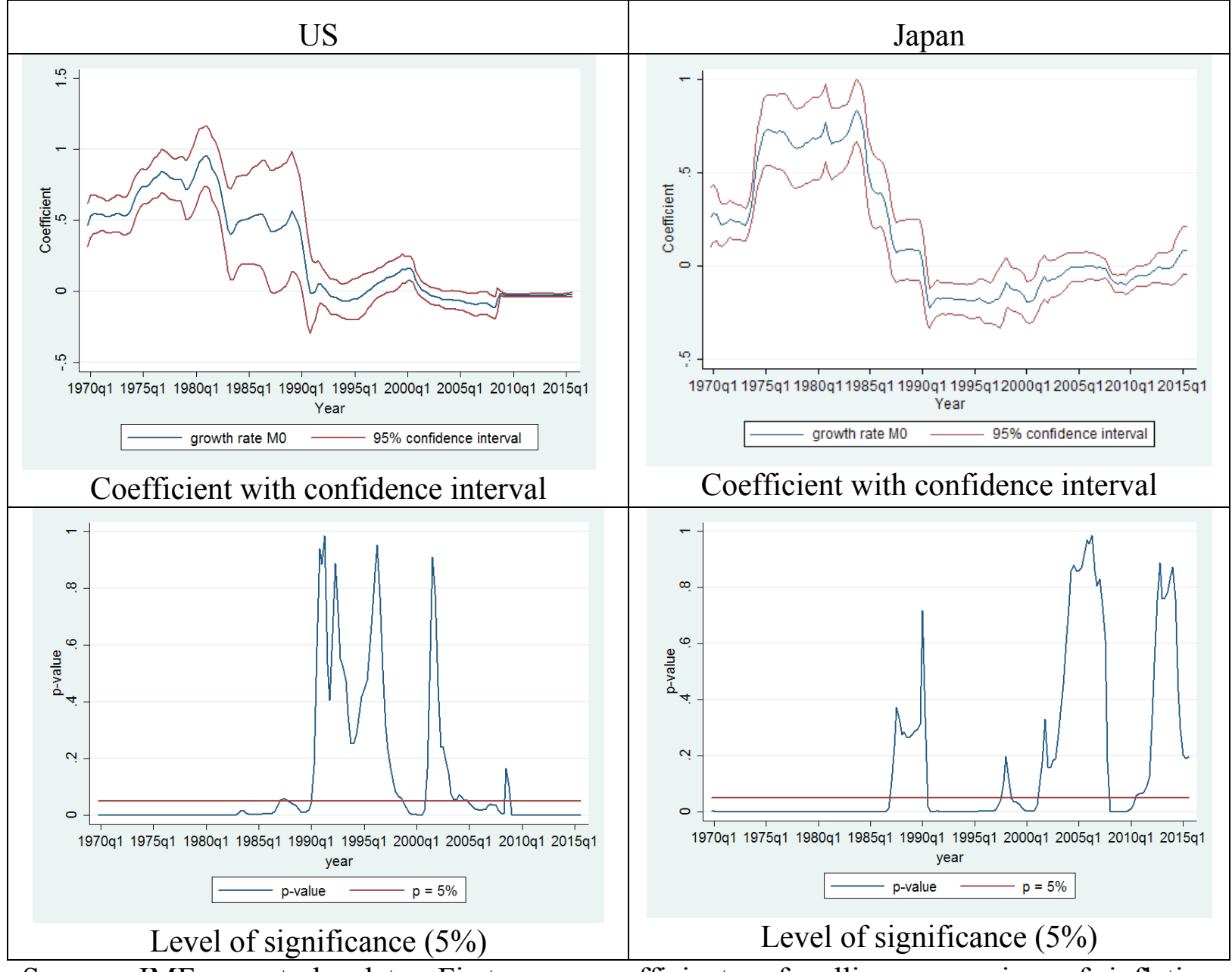

Source: IMF, quarterly data. First row: coefficients of rolling regression of inflation (backward weighted ten-year window) on the growth rate of the monetary base (minus real growth); second row: p-values of the rolling regressions.

If rational commercial banks anticipate the monetary tightening in the case of rising inflation, they may funnel the additional liquidity provided by the central bank to the financial sector, for instance in form of real estate financing and financing of other asset purchases (e.g. stocks and raw materials). Then, asset prices instead of consumer prices will increase (see citation by 
Schumpeter (1912) in section 2.1). ${ }^{16}$ Because consumer price indices used by central banks to measure inflation do not contain asset prices (such as real estate or stocks) and thereby reflect asset price increases only indirectly, consumer price inflation remains low. This effect is even larger, when - as for instance in Japan since the bursting of the bubble in December 1989 the domestic monetary expansion feeds credit growth abroad.

Given an inflation targeting framework the financial institutions profit more from funneling the credit flows into the financial sector (than into the enterprise and household sector) for at least five reasons. First, given declining interest rates the volumes of credit increase, which implies additional turnover. Second, the commission returns for intermediating financial transactions (including mergers and acquisitions) increase. Third, as financial institutions tend to hold assets such as stocks and real estate the book value of these assets increases. This, forth, implies growing values of collateral for additional transactions. Fifth, if central bank crisis management can be anticipated, the asymmetric nature of monetary policy is equivalent to an insurance mechanism for losses on financial investment (and speculation).

The upshot is, that there is an incentive to circumvent the monetary policy rule as a control mechanism against undue credit growth, because the profits of financial institutions grow fast during the upswing. Even if the bursting of the bubble is anticipated, the incentive for a single rational financial agent not to participate in the boom is low. The personal income flows during the financial boom would be substantially smaller compared to financial agents participating in the boom. In case of financial crisis, monetary policy crisis management can be expected to prevent asset prices from falling or to push up alternative investment classes to compensate the losses. ${ }^{17}$ Therefore, even in the case of financial crisis, the income flows of prominent financial markets agents are likely to remain high (see section 4.3).

16 This is an important innovation of this paper and a deviation from Wicksell $(1898,1936)$, who did primarily not address stock markets. Nevertheless, Wicksell (1936: 95) acknowledged that interest rates and credit conditions affect real estate markets: "Even more convincing is the case where the money is used for durable investment. Let us suppose that there is a general fall in the rate of interest from 4 to 3 per cent. We have seen that the value of all permanent capital goods, for instance of dwelling-houses, will go up by 33 per cent. (...) Rents will rise, and while it is true that the owners of houses will spend proportionately more on such things as repairs, it is to be presumed that their net return will go up in proportion. This will bring about a further rise in the price of houses (though not the full equivalent of the original rise), and so indirectly a further rise in the prices of everything else (...) An abnormally large amount of investment will now probably be devoted to durable goods. There may result a relative overproduction of such things as houses and a relative underproduction of other commodities."

17

During the upswing in particular the upper management (as agent) can privatize major parts of the (speculative) profits, for instance in form of bonuses. Once the bubbles burst, the resulting losses during the downswing may be shifted to the owners of the financial institution (stock holders), i.e. the principal (bail in). Alternatively, the costs of the rescue measures are shifted to the public sector directly via public bail outs 
Through this mechanism an ultra-loose monetary policy can lead to falling - rather than increasing - inflation as measured in the usual consumer price indices for at least four reasons. Firstly, in many cases central bank interest rate cuts and the expansion of the monetary base were/are accompanied by excesses in real estate markets and go usually along with booms in the construction industry. The impact of fast increasing real estate prices on consumer price indices remains limited. Although prices for new rentals (in particular in centers of economic activity) may rise, housing market regulations dampen any transmission from rising real estate prices to average home rental rates. As rents represent housing in the consumer price baskets, the transmission of fast growing house prices to consumer price baskets is weak. In the long term the creation of additional capacities can dampen home rental rates after the burst of the bubbles.

Secondly, low interest rates constitute lower costs for credit. In the case of boom phases in the stock markets they also cause favorable conditions to raise capital via stock emission. This contributes to lower costs of enterprises, in particular large enterprises, which can issue stocks. Bearing in mind the significant increase in global competition following the entry of China and many Central and Eastern European countries into the world economy, the declining financing costs are likely to have contributed to lower prices in the product markets. Thirdly, financial institutions can use the additional liquidity to purchase government bonds, meaning that government spending will continue to grow. A shift in demand from the private to the public sector and therefore price increases of goods consumed by the public sector is not reflected by the established consumer price indices. Fourthly, the distributional effects of boom-and-crisis cycles in the financial markets indirectly bring about income repression for major parts of the population (see section 4.3). This dampens consumption among those sections of the population, whose consumption habits are modelled in the consumer price indices of central banks.

and/or indirectly via monetary expansion. This reduces the incentives for the principal to take sanctions against the agent. This is equivalent to the circumvention of the liability principle of market economies. 


\subsection{Crisis Management and Financial Market Exuberance}

The gradual monetary expansion of central banks in the course of crisis management has come along with a gradual growth of financial markets, as the asymmetric monetary expansion provided an incentive to expand debt at lower interest rates. ${ }^{18}$ In the US, the size of the financial and real sectors (which are strongly intertwined) as a share of the total economy increased from $11 \%$ in 1980 to $18 \%$ by 2015 (Figure 7). ${ }^{19}$ Together with the size of financial markets also volatility seems to have increased. According to Mises (1949: 572), "[t]he wavelike movement effecting the economic system, the recurrence of periods of boom which are followed by periods of depression is the unavoidable outcome of the attempts, repeated again and again, to lower the gross market rate of interest by means of credit expansion." In liberalized and globalized financial markets, the effects of domestic monetary policy crisis management can emerge in any other country or any market segment of globalized financial, real estate and raw material markets (Hoffmann and Schnabl 2016a).

The growth of financial markets went along with a boost in financial market deregulation, which spread across all industrialized and many emerging market economies. The growth of financial markets can be either seen as the outcome or as the motivation of financial deregulation. For instance, Dell'Arricia et al. (2012) see financial deregulation as a precondition for the growth of financial markets (and possible financial crisis). Assuming a gradual monetary expansion as exogenous (as in Hayek 1931) the gradual interest rate cuts can be seen as the prerequisite for credit creation and investment in financial markets. If gradual interest rate cuts create additional profit opportunities in new market segments, financial institutions would have an incentive to use parts of the expected profits to lobby for financial deregulation. This financial market deregulation could take the form of liberalizing new market segments in domestic financial markets or opening up whole countries for international financial flows (as for instance China)y.

18 Wicksell (1936: 233): "In depressed times when they usually suffer from an excess of cash, the banks should reduce their loan rates of interest early and energetically, just as they should raise them early, at the outset of good times, both in order to prevent excessive speculation and unsound ventures and to stimulate saving."

19 Concerning the complementary development in China in context of US monetary and Chinese exchange rate and monetary policies see Schnabl (2012). 
Figure 7: US Financial and Real Estate Sector as Share of the Total Economy

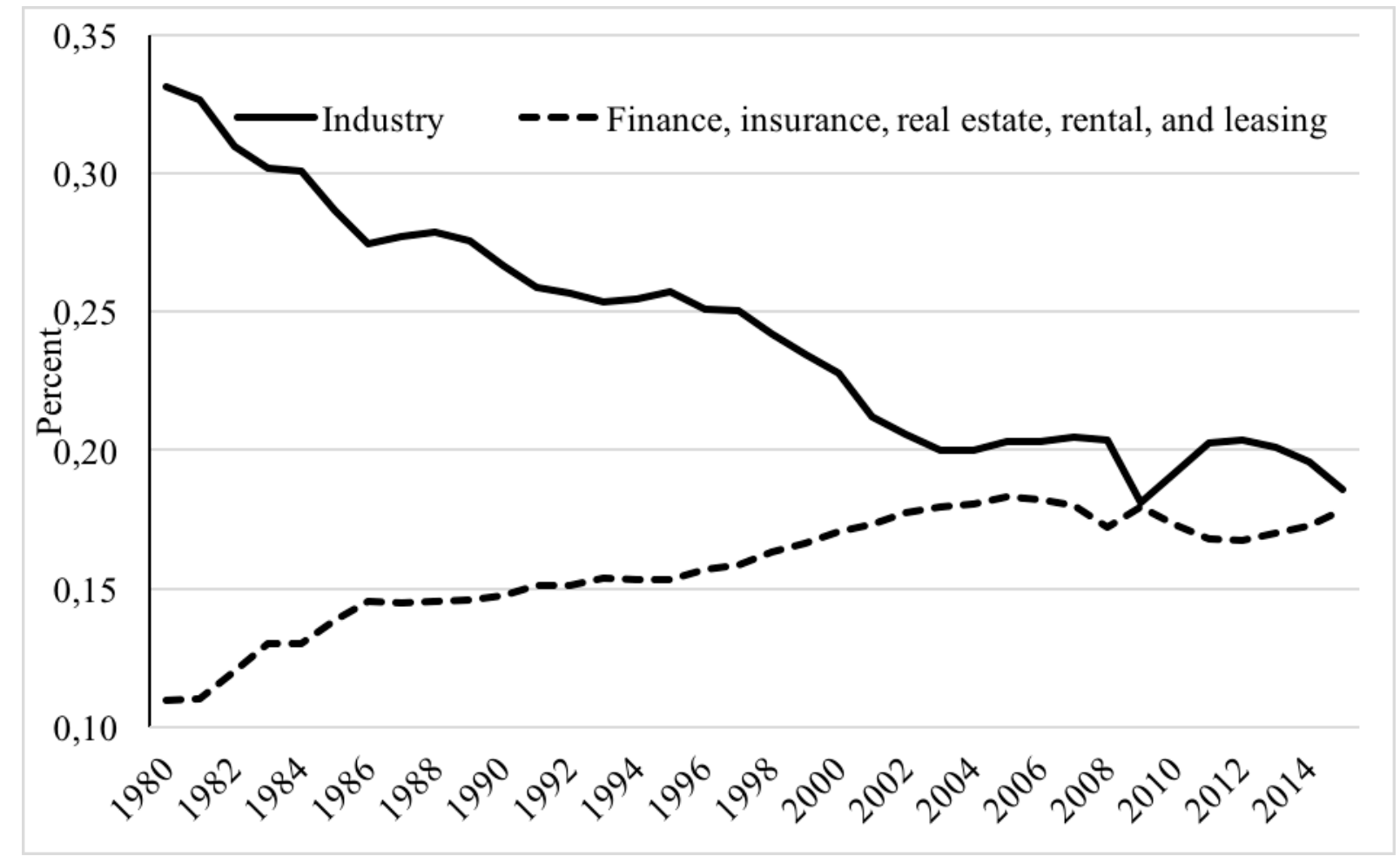

Source: US Bureau of Economic Analysis.

With the benefit of hindsight, a wave of wandering bubbles (see Schnabl and Hoffmann 2008) can be identified. In Figure 8 the wave of wandering bubbles starts in Japan in the mid 1980s, when Japan was forced to let appreciate the Japanese yen to cure the US-Japanese trade imbalance (Sept. 1985 Plaza Agreement). As the strong yen appreciation by about 50\% against the dollar pushed the export dependent Japanese economy into a deep recession, the Bank of Japan cut interest rates from 8\% (Sept. 1985) to a by then historical low of $3.5 \%$ (Sept. 1987). While the eased financing conditions facilitated investment to reduce production costs of the export enterprises, the cheap liquidity also nurtured an unprecedented speculation boom in stock and real estate markets, which peaked in December 1989 (see Nikkei in Figure $8)$.

As in the overinvestment theories, the Bank of Japan pricked the bubble by increasing interest rates, when it started to regard the development on stock and real estate markets as unsustainable. Whereas monetary policy was kept tight in the early phase of the post-bubble recession (as assumed by the monetary overinvestment theories) the advent of the lasting post-bubble recession finally tempted the Bank of Japan to ease monetary conditions even 
further, by cutting interest rates gradually towards zero. Japanese money market interest rates reached $0.5 \%$ in 1995 and remained close to 0\% since March 1999.

\section{Figure 8: Wandering Bubbles}

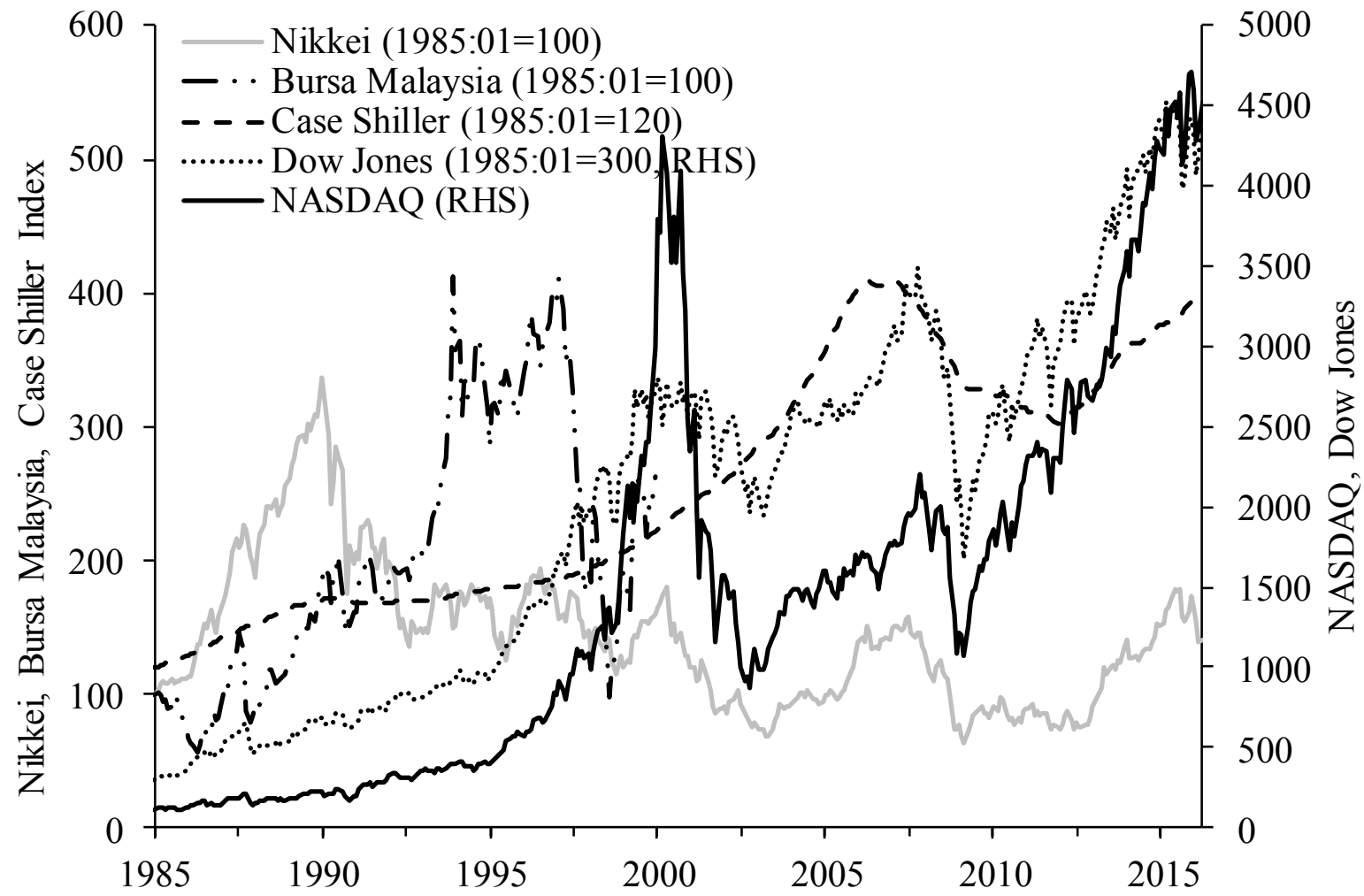

Sources: Nikkei, Reuters, NASDAQ Stock Market, Standard \& Poor's, Dow Jones. Based on Hoffmann and Schnabl (2008).

But instead of expanding credit to the domestic economy, the ailing Japanese banks provided credit to banks and enterprises being active in a set of Southeast Asian economies. Stock and real estate bubbles in the Southeast Asian (now miracle) economies emerged, as represented by the Malaysian stock market in Figure 8. In June 1997, the speculation boom in Southeast Asia finally turned sour as international capital markets had lost confidence in the regional boom. During the Asian crisis, which was accompanied by the Japanese financial crisis (because Japanese banks and export enterprises were strongly engaged in the region), capital flows returned to the save haven of the industrialized countries. With the central banks of the large industrialized countries having responded to the Asian crisis and Japanese financial crisis (as well as to buoyant capital inflows) by interest rate cuts, bubbles in the so-called dotcom market emerged (see NASDAQ in Figure 8). 
The bursting of the dotcom bubbles in December 2000 triggered new interest rate cuts in the large industrialized countries, which built the breeding ground for a set of new, ever larger bubbles. Figure 8 shows the Case-Shiller Index as a proxy for the US-subprime boom. Beyond the US, in set in European periphery countries (including Greece, Ireland, Portugal, Spain, the Baltics, Iceland, etc.) stock and real estate bubbles emerged, which were accompanied by private and public spending booms. ${ }^{20}$ Given the low interest level in the US, also China was faced with speculative capital inflows, which significantly contributed to a build-up of overcapacities in the Chinese (export-)industry and the real estate sector (Schnabl 2016). The Chinese boom - which triggered growing demand of China for raw materials was accompanied by hiking prices for oil, gas and raw materials.

The outbreak of the US subprime crisis was followed by crises in the periphery countries of the euro area and other European periphery countries. The following monetary policy crisis management of Fed and ECB helped to reverse the dips in the global raw material markets and in China until confidence in the Chinese economic miracle started to fade from $2014 .^{21}$ Since then, as the overcapacities in China have become visible, the bubble in the raw material markets has burst and China's growth rates are on continuous decline. Increasing amounts of capital are invested in the US stock markets (see NASDAQ and Dow Jones in Figure 8) and the stock markets of some northern European countries, in particular Germany. In short: the new bubbles seem to emerge in the industrial sectors of the industrialized countries, as previous bubbles have undermined the confidence in the financial institutions in industrial countries and the industrial capacities of the emerging market economies (in particular China).

\section{Growth and Distribution Effects of Monetary Policy Crisis Management}

The upshot is that from a global perspective the monetary policy crisis management of today is the breeding ground for the overinvestment and speculation booms of tomorrow, and the financial crises of the day after tomorrow. Whereas in the face of crisis, monetary policy crisis management helps to stabilize financial markets in the short-term, it has a growing number and scale of unintended side effects in the form of quasi unpredictable bubbles in some -

\footnotetext{
20 See Schnabl and Wollmershäuser (2013) on the asymmetric effects of ECB monetary expansion on different parts of the European Monetary Union (and beyond).

${ }^{21}$ On the overinvestment boom in China see Schnabl (2016).
} 
more or less random - segments of international financial markets. Once bubbles have burst, in many cases a lasting stagnation is observed, which can be attributed to two main reasons.

First, as argued by Koo (2003) balance sheet recession puts a drag on growth. Declining stock, real estate prices and consumer prices increase the real value of debt. As the value of collateral of credit declines, households and enterprises are forced to curtail consumption and investment to reduce their debt burden. Such balance sheet recessions are argued to be longer and deeper than usual recessions also because the financial sector is strongly damaged (Reinhart and Reinhart 2010, Dell'Arricia et al. 2012). They are associated with permanent output losses due the pre-crisis overestimation of potential output, the misallocation of capital stock and labor during the upswing and the oppressive effects of debt and capital overhangs during the downswing. The implicit consequence is that growth will recover, once the adjustment process to real debt is finished.

Focusing on the notion of misallocation of capital sections 4.1. and 4.2 are extensions of the theories of Mises (1912) and Hayek (1929) fitted to explain lasting stagnation not only as the heritage of pre-crisis exuberance (as in Reinhart and Reinhart 2010 and Dell'Arricia et al. 2012), but also as a consequence of the monetary policy crisis therapy (in contrast to Dell'Arricia 2012). They are developed in the notion of Hayek (1931: 98) that if "voluntary decisions of individuals are distorted by the creation of artificial demand, it must mean that part of the available resources is again led into a wrong direction and a definite and lasting adjustment is again postponed." Section 4.3 provides insights into possible redistribution channels of the unprecedented monetary expansion in the industrialized world (with their repercussions on consumer price indices and thereby inflation targeting). Section 4 has to be seen as the starting point for more research on the unintended side effects of monetary policy crisis management.

\subsection{Declining Productivity Gains}

The most important argument in favor of bail outs of financial institutions during crisis is the potential credit crunch (Koo 2003). When asset price bubbles burst, bad loans in the banking sector increase, as debtors are rendered over-indebted. The resulting shrinkage of equity forces banks to tighten credit to the private sector. As the resulting credit crunch threatens to extend the crisis to the enterprise sector (with a respective rise in unemployment), interest cuts 
and low-interest (no-cost) liquidity provision by the central bank shall stabilize both the financial and enterprise sector (Posen 2000). As the bad-loan problem in the financial sector is contained, contagion effects to financial institutions and enterprises are prevented. However, a highly expansionary monetary policy during crisis - which is not followed by a symmetric monetary tightening - leads in the long term to a quasi-nationalization of money and credit markets.

In money markets - given growing distrust among banks during crisis - interbank lending of commercial banks is substituted by borrowing from and depositing at the central bank. The zero interest-rate policy perpetuates this situation, because profit margins in money markets are compressed (McKinnon 2012). Banks with excess liquidity no longer have any incentive to supply overnight credit. Even if banks requiring liquidity were to offer higher interest rates to create a supply, the loan is unlikely to be granted, because offering high interest rates signals higher risk. ${ }^{22}$ As a result, the private supply in money markets is substituted by the central bank. Banks with excess liquidity invest with the central bank.

In the credit markets the zero interest-rate policy contributes to a credit crunch, because the low- or zero-interest rate policy is equivalent to a subsidy for the enterprise sector, which is under usual circumstances an aggregated demander on the lending market. Especially for large companies that can issue their own securities and stocks, financing costs drop. The declining costs of obtaining capital give rise to additional profits for - in particular large enterprises, which becomes visible in the form of increasing corporate savings. ${ }^{23}$ The demand for loans declines and outstanding credit is repayed. (Increasingly) own shares are bought back, because alternative investment categories (bank deposits, government bonds) render low yields due to the asymmetric monetary policy crisis management. ${ }^{24}$

22 This is equivalent to a market failure as in Ackerlof (1970).

23 It is therefore difficult to provide sound empirical evidence for the hypothesis of the global liquidity glut as launched by Bernanke (2005). The assumed structural increase in net household savings because of aging societies cannot be observed in any of the ageing countries with surplus savings (over investments) (see upper panel of Figure 10). The increase in aggregate net savings surpluses in these countries (relative to investments) is rather due to the increase in corporate savings (especially resulting from declining financing costs) and the fall in investments.

24 This increases the profit per share and therefore - in many cases - the bonus payments for the upper management (see section 4.3). 
Figure 9: G3 Household and Enterprise Savings (as a Share of GDP)
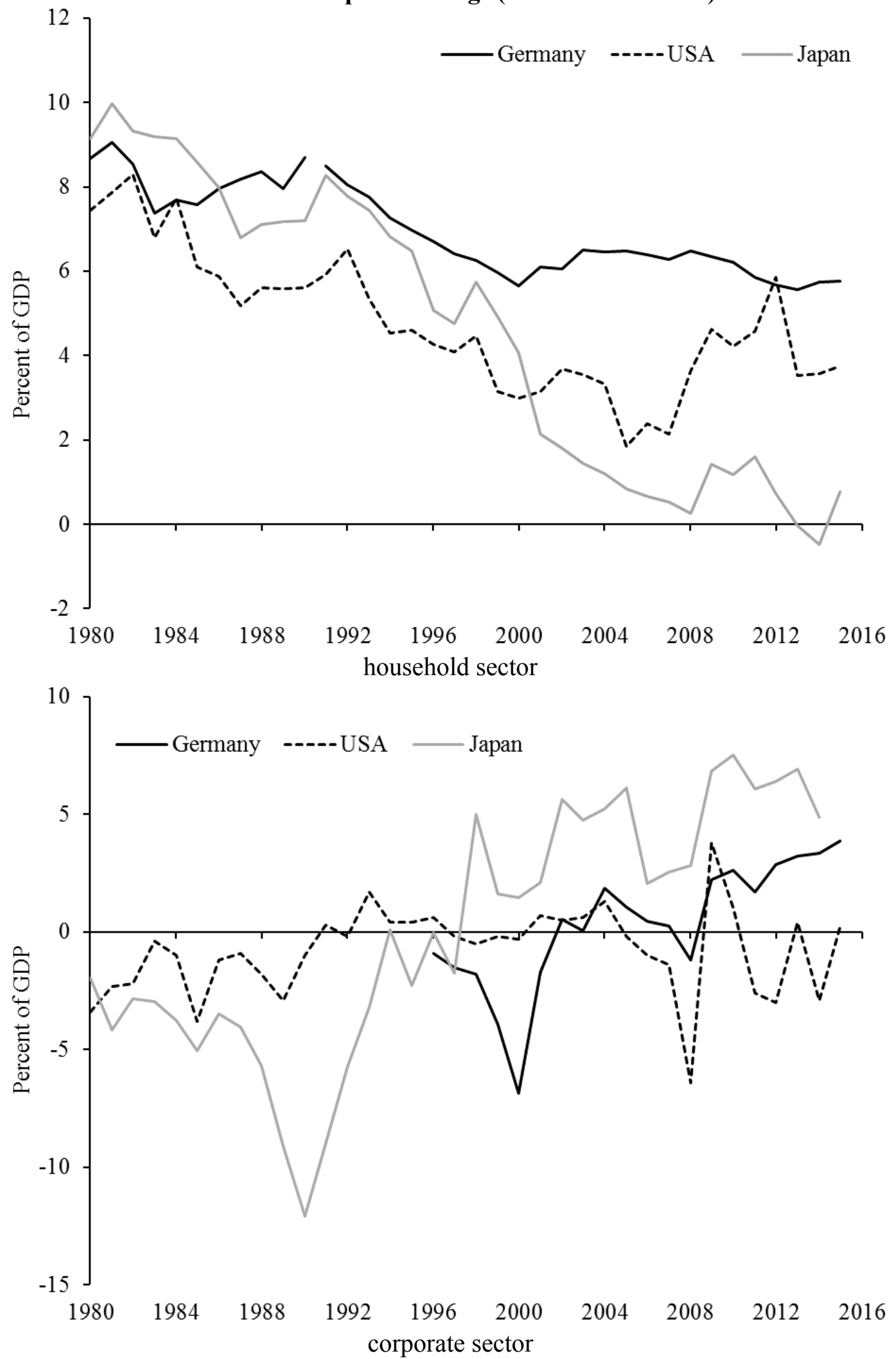

Sources: OECD, Cabinet Office (Japan), Federal Reserve (USA). Household Savings are defined as total disposable income of households less total final consumption expenditure. Enterprise savings are defined as the net acquisition of financial assets less incurrence of liabilities by non-financial corporations. 
If the larger, less risky companies withdraw from the loan portfolios of commercial banks, the average risk in the banks' loan portfolios increases. In this case loans to comparatively highrisk small and medium-sized enterprises have to be restricted. In particular, new and risky investment projects by small and medium enterprises will tend to remain unfinanced. If the banks are more strictly regulated as a result of financial crisis, they need to accumulate more equity, which is an additional incentive to restrict lending to higher-risk companies. As lending to the government is widely acknowledged to be riskless (because of respective regulations such as Basle III and because of asymmetric monetary policy crisis management), lending to the private sector tends to be substituted by lending to the public sector. ${ }^{25}$

In contrast, credit to enterprises and households having been granted before the crisis has a high probability of being extended despite low credit worthiness. To remain in the market, banks in trouble tend to disguise their bad-loan problem by overlooking precarious business situations of enterprises. For Japan - where the (close to) zero interest rate period persists the longest - Sekine, Kobayashi and Saita (2003) find forbearance lending: Banks continue to provide irrecoverable loans, thus keeping themselves and (potentially) insolvent companies alive. Peek and Rosengren (2005) associate Japan's central bank crisis management with a misallocation of capital in the credit sector, which keeps companies with poor profit prospects alive (“evergreening”).

This implies a structural change in the nature of banking business. Traditional banking involves accepting deposits with a positive rate of return and lending that capital, in the form of loans, to businesses and households at higher interest rates. Banks fulfil an intermediary function making an assessment about the future returns on investments. Projects with higher expected returns than the prevailing interest rate are financed at a given interest rate. Projects with lower expected returns (with a high probability of default) are rejected. By having accumulated the know-how to make this assessment properly, the banking sector has been traditionally playing a crucial role in the allocation function of the interest rate, separating investment projects with higher marginal productivity from those with lower marginal productivity.

(see section 4.3).

25 This is in particular the case, if national debt increases in the course of the crisis management as observed in Japan and many European crisis countries. This effect vanishes, when interest rates on government bonds turn negative. 
If the banking system is, however, no longer subject to strict budget constraints due quasiunlimited central bank liquidity provision in the course of monetary policy crisis management, the allocation function of the interest rate is undermined. Kornai (1993) spoke of "Soft Budget Constraints" in the case of the Central and Eastern European planned economies: Since unemployment was politically undesirable, non-profitable companies were kept alive by covering their losses via the state-controlled banking systems. Quian and Xu (1998) showed for China that such soft-budget constraints made it harder to separate profitable from unprofitable projects as the selection mechanism of the market was undermined. Caballero, Hoshi and Kashyap (2008) show for Japanese companies that under zero interest rate policies profits became dependent on cheap central bank liquidity provision. Thus, while the monetary policy crisis management successfully helped keeping unemployment low, it went globally along with declining average productivity increases of firms (Figure 10).

\section{Figure 10: G3 Productivity Increases}

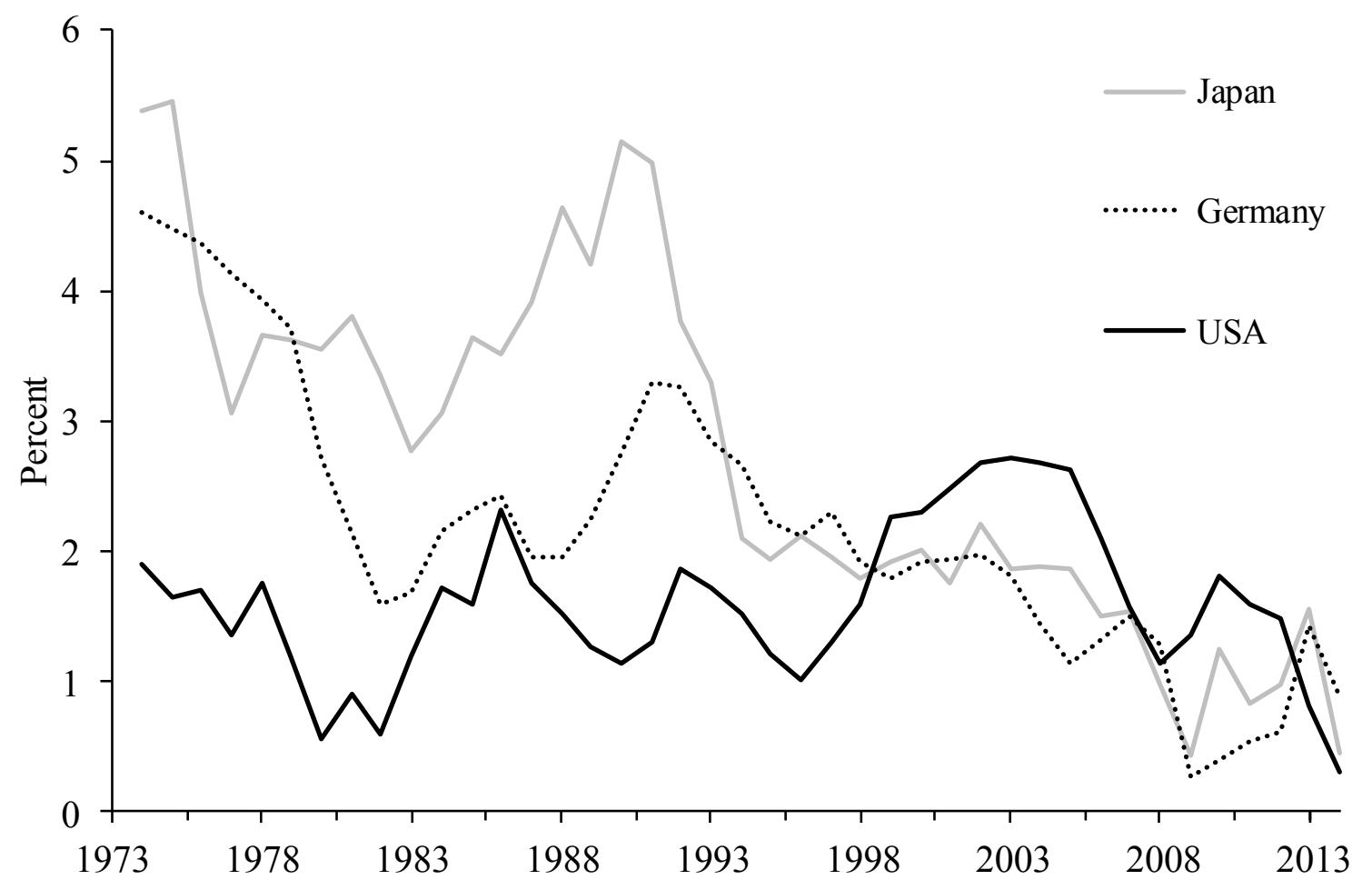

Source: OECD.

Similar developments seem to take place in other industrialized countries, in particular since the advent of zero interest rate policies (see Figure 10 for the US and Germany). Barnett et al. (2014) demonstrate that since 2007 the United Kingdom has experienced a significant drop in 
productivity growth among businesses. Cardarelli and Lusinyan (2015) show for the US that total-factor productivity has dropped significantly since the turn of the millennium. Gopinath et al. (2015) provide respective empirical evidence for the Southern European countries since the outbreak of the European debt and financial crisis.

The upshot is that monetary policy crisis management delays or prevents the structural adjustment process during crisis as stressed by Schumpeter (1912): the cleansing process, which is regarded in the monetary overinvestment theories as a prerequisite for a sustained recovery, is postponed. Investments which would have to be dismantled at Wicksell's (1898) natural rate of interest continue to be financed, what implies that the average efficiency of investment gradually declines below Hayek's and Wicksell's natural interest rate. ${ }^{26}$ This interpretation is line with Borio (2014), who identifies capital overhang as a major determinant of post-bubble crisis.

\subsection{Impact on Investment and Growth}

Given gradually declining productivity increases asymmetric monetary policy crisis management can affect investment in fixed assets negatively for several reasons. First, resources are bound in investment projects with low productivity, whereas new investment is discouraged by the ailing banking sector (see section 4.1). Second, because the ample liquidity provision in the course of monetary policy crisis management prevents asset prices from further falling (or drives prices upwards in alternative asset classes), monetary policy crisis management constitutes an implicit insurance mechanism for investment and/or speculation in financial markets. In contrast, enterprises have to bear the risk of investment in new products or production processes without any public insurance mechanism. Therefore, enterprises have incentives to substitute investment in real investment projects by financial investment, including repurchases of own stocks (see section 4.2.). ${ }^{27}$

26 In the monetary overinvestment theories, too favourable refinancing conditions during the upswing cause additional investment projects with lower expected returns to be financed. The marginal and average efficiency of investments decreases. During downturn and crisis, investment projects with low internal rates of return are cancelled. The marginal and average efficiency of investments increases. In the long term, the average efficiency of investment is therefore mainly constant. In contrast von Weizsäcker (2015), Summers (2014) as well as Laubach and Williams (2014) assume a gradual secular decline of the average return on investment, what they assume to be matched with a secular decline of what they call natural interest rate.

27 From a private sector perspective, the average return on financial investments will seem relatively high if potential losses are counteracted by the central bank. In aggregate, however, the overall returns need to be adjusted for possible state subsidies. This is for example the case when banks are recapitalized with public money, or the costs of bailouts in the course of central bank crisis management become visible e.g. in the 
Third, if the financial crisis is transformed into a sustained crisis in which there is no limit to the central bank's government bond purchases, the likelihood increases that private investments is substituted by public investments and/or government consumption. ${ }^{28}$ For instance, after the Japanese bubble had burst in December 1989, numerous Keynesian economic stimulus programs were implemented (Yoshino and Mizoguchi 2010, Fischer and Schnabl 2016). Figure 11 shows that gross investment in Japan as a share of GDP declined from $32 \%$ since the bursting of the bubble in the year 1990 to $20 \%$ in the year 2014 , whereas government spending as a share of GDP rose from 13\% to 19\%. Assuming that public investments have a lower marginal efficiency than private investments, the average efficiency of investments has further decreased.

\section{Figure 11: Structure of Japans Gross Domestic Product}

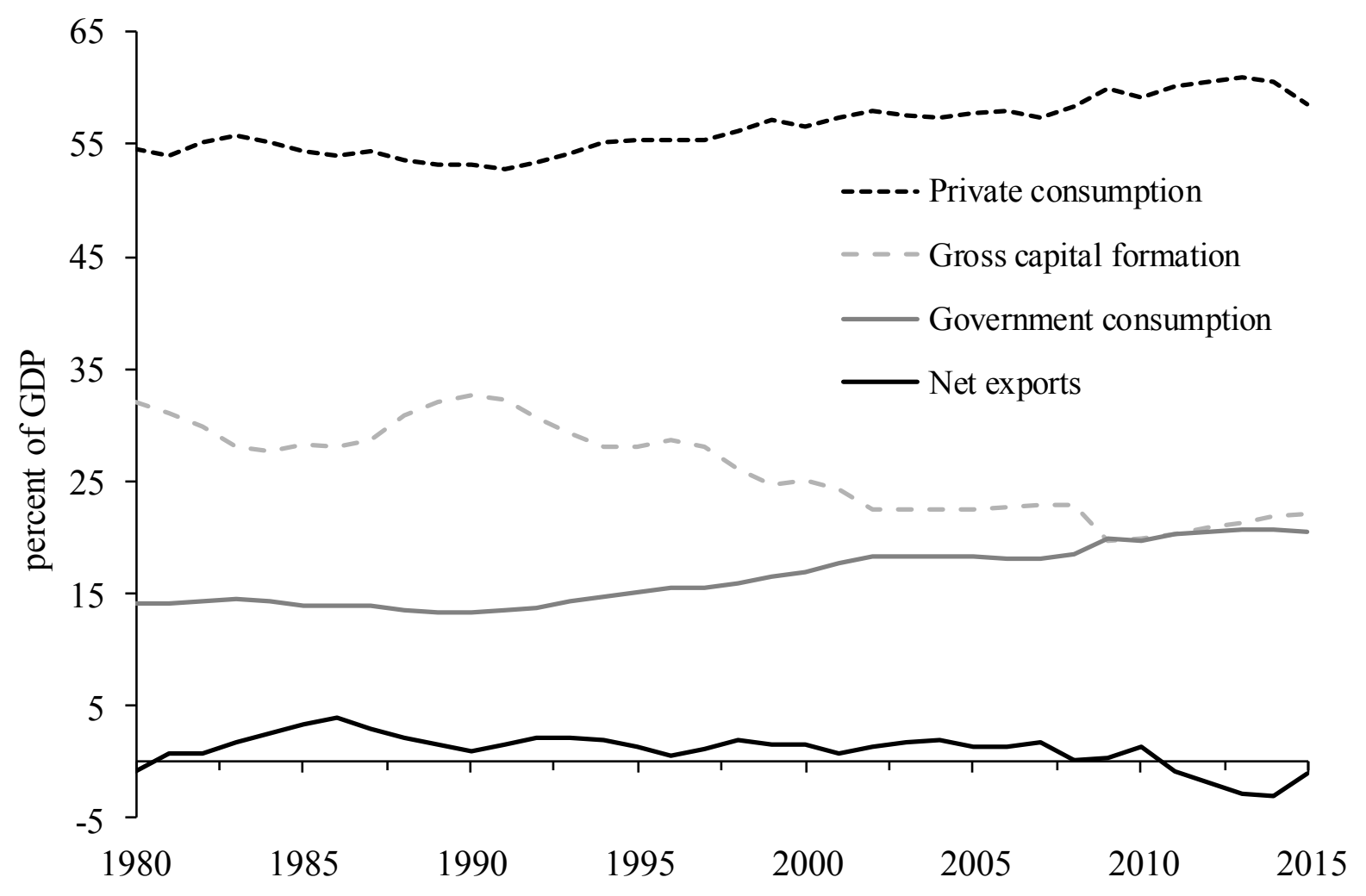

Source: Cabinet Office (Japan).

In the neoclassical growth theory, growth is explained by the accumulation of capital towards a long-term equilibrium between investment and depreciation (steady-state economy). The 
steady state is based on the assumption of a declining marginal efficiency of capital when the stock of capital increases (Solow 1956, Swan 1956). Only, through innovation and technological progress, which can be interpreted as increasing productivity, can growth be positive in the long term (Solow 1957). In this framework, an asymmetric monetary policy crisis management negatively affects growth if it has a negative impact on innovation and productivity gains.

Figure 12: G3 Investment as Share of GDP and Real Growth

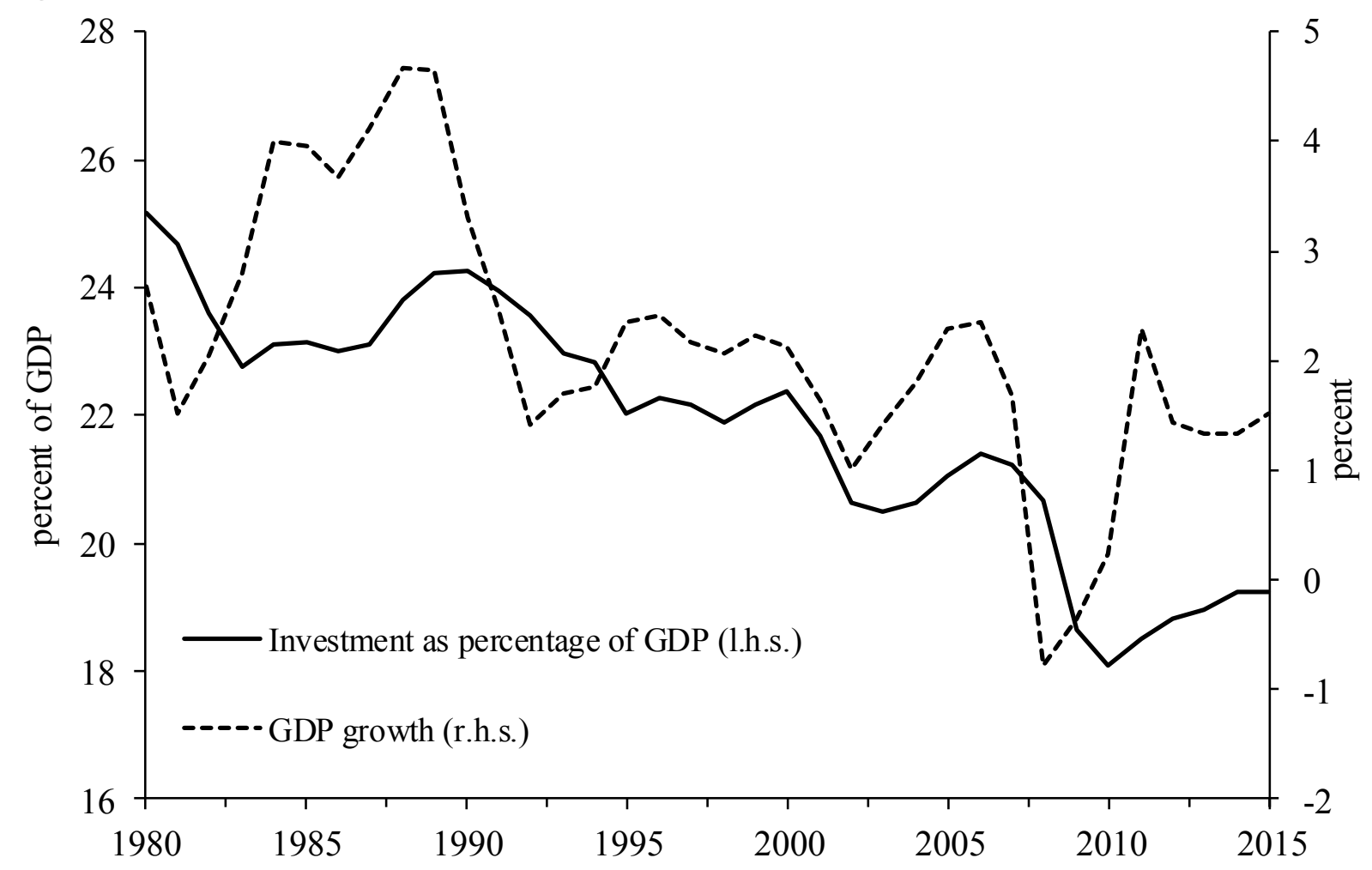

Source: OECD, Cabinet Office (Japan), BEA, Eurostat. Three-country arithmetic averages.

Leibenstein (1966) regards incentives and motivation as major determinants of a concept of efficiency which goes beyond allocative efficiency (assuming constant production costs in different types of markets such as polypolies in contrast to monopolies) (X-(in)efficiency). Businesses do not realize all possible efficiency gains when competition is limited. Such Xinefficiency can arise when asymmetric monetary policy crisis management results in the creation and cementation of structural distortions. ${ }^{29}$ In the course of asymmetric monetary

29 On the impact of credit booms on the allocation of labor and productivity dynamics see also Borio et al. (2016). 
policy crisis management, liquidity and loans are provided increasingly independently from efficiency criteria, causing the average productivity of zombie firms supported by zombie banks to decline. Loan provision to new dynamic enterprises becomes more restrictive. A reduced pace of innovation, which according to Hayek (1968) is triggered by lower levels of competition, have a negative impact on productivity gains.

By tying resources to sectors with low or negative productivity gains, in the context of the Solow-Swan model a negative allocative effect is created which results from declining average productivity (defined as output per unit of labor). From the perspective of companies, average costs will rise ceteris paribus. At the macroeconomic level, fewer goods and services are produced with a constant amount of labor. Since declining output also entails a decrease in savings per worker, this results in an additional negative growth effect because households make fewer savings available for investment.

A further determinant favoring lower growth is declining household savings as shown in Figure 10 and, coupled with this, declining investments, which result from reduced incentives for people to save. The transmission channel from monetary policy crisis management towards reduced savings activity is financial repression, which drives down returns on lowrisk investments. Real household savings fall as shown in Figure 9, meaning that real investments also fall and in turn production opportunities increase less. ${ }^{30}$ Once depreciations exceed gross investment, the result is a downward spiral of declining returns on capital, households saving less, declining investments and declining output. As seen in Figure 12, real growth rates in the large industrialized countries are gradually falling together with investments as a share of GDP.

\subsection{Redistributive Effects via Financial and Real Wage Repression}

Asymmetric monetary policy crisis management has redistribution effects, which work through a large number of diverse transmission channels (see Hoffmann and Schnabl 2026b). Cantillon (1931) stressed the redistribution effects of monetary expansion in favor of the

\footnotetext{
30 Similar reasoning can be found in McKinnon (1973) and Shaw (1973), who identified by then financial repression as a major obstacle to growth in developing countries. ${ }^{31}$ This hypothesis is constitent with de Haan and Sturm (2016) if financial liberalization and credit growth is acknowledged as the outcome of gradual monetary expansion.
} 
banking system relative to other parts of the economy (Cantillon Effect). ${ }^{31}$ Given a monetary expansion by the central bank, commercial banks not only benefit from accelerating credit growth, they can also acquire stocks, real estate and securities etc. at still constant prices. If the sellers of these assets use or provide the received funds for new purchases in these asset classes, real estate, stock and security prices have already increased. This implies a redistribution effect in favor of banks and at the cost of agents, which are more remote from the central bank's liquidity provision.

Such redistribution effects in favor of the financial sector are for instance visible in the United States, which is the country with the largest and most developed financial markets. As shown in Figure 13 until the mid-1980s the wages of industrial sector workers grew faster than in the financial sector. Since the mid-1980s - with the start of the asymmetric monetary policy crisis management - financial sector employees are benefitting from higher wage increases. This was even the case in financial market crises, during which industrial workers' wages declined more than in the financial sector. Financial sector executives may benefit more than other employees from windfall profits during speculative upswings, because one-off dividends (bonuses) are more common at this level.

\section{Figure 13: Wage Development in the US Financial and Manufacturing Sectors}

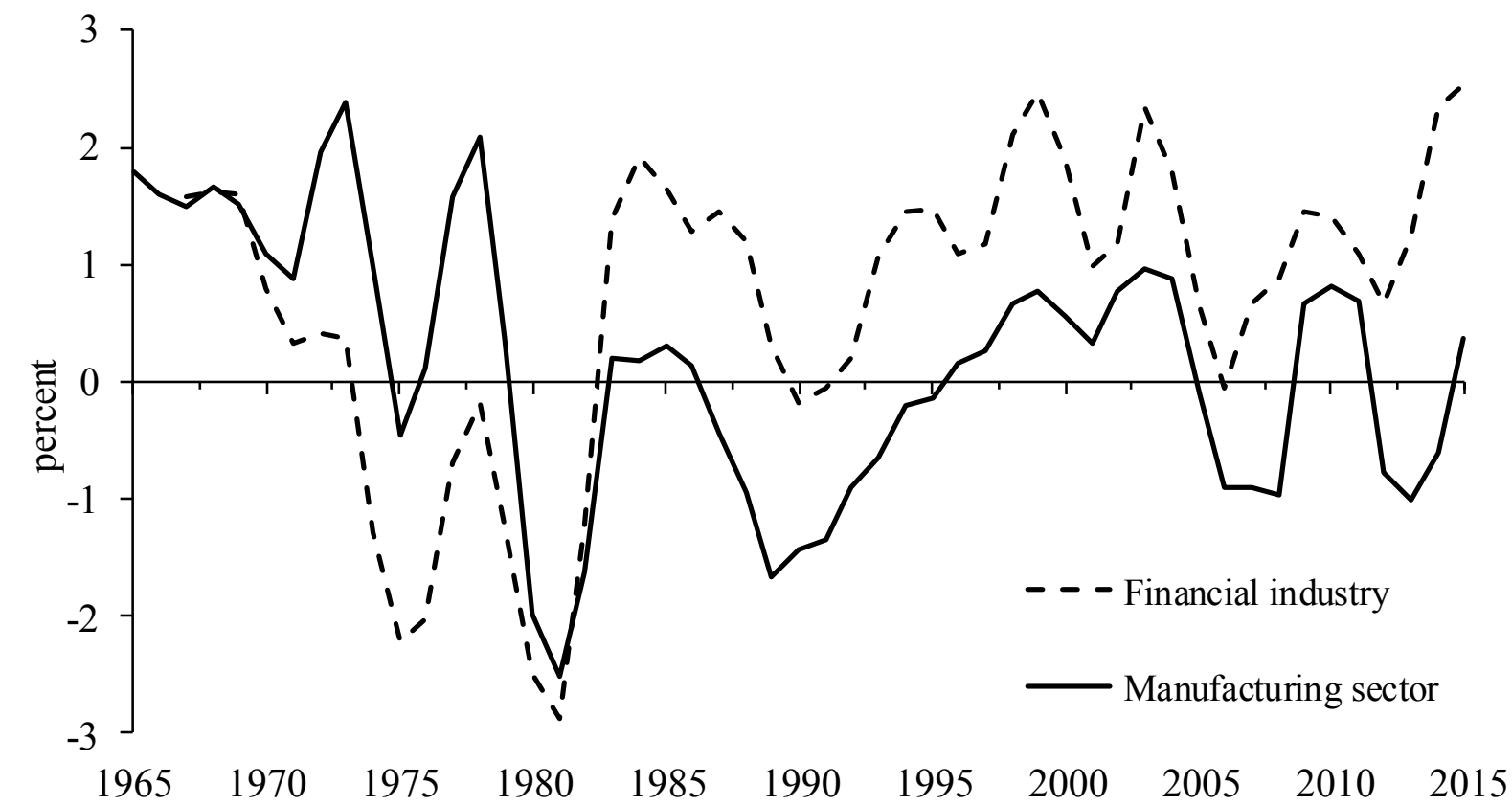

Source: IMF, BLS.

31 This hypothesis is constitent with de Haan and Sturm (2016) if financial liberalization and credit growth is acknowledged as the outcome of gradual monetary expansion. 
An important transmission channel from asymmetric monetary policy crisis management to diverging wealth and income is via its impact on asset prices, because assets such as stocks and real estate are unevenly distributed among different wealth and income groups. If an asymmetric monetary policy is geared towards pushing up asset prices, it redistributes in favor of high-income groups, which tend to hold these asset groups over-proportionally. This is suggested by Figure 13 of which the left axis shows price trends on the US and Japanese stock markets (NYSE and Nikkei), whereas the right axis plots the share of the top $1 \%$ of incomes as a proportion of total incomes of the US (including income from capital). The rise of the share of top $1 \%$ incomes as a share of total incomes goes along with the rise of Japanese stock prices during the 1980s. Since 1987, when Alan Greenspan took office as Chairman of the Federal Reserve and initiated a monetary policy aimed primarily at stabilizing the financial markets, the share of the top $1 \%$ of incomes in the US has risen from around $13 \%$ to almost $22 \%$ of total income together with US stock prices.

\section{Figure 14: Stock Prices (US, Japan) and US Income Distribution}

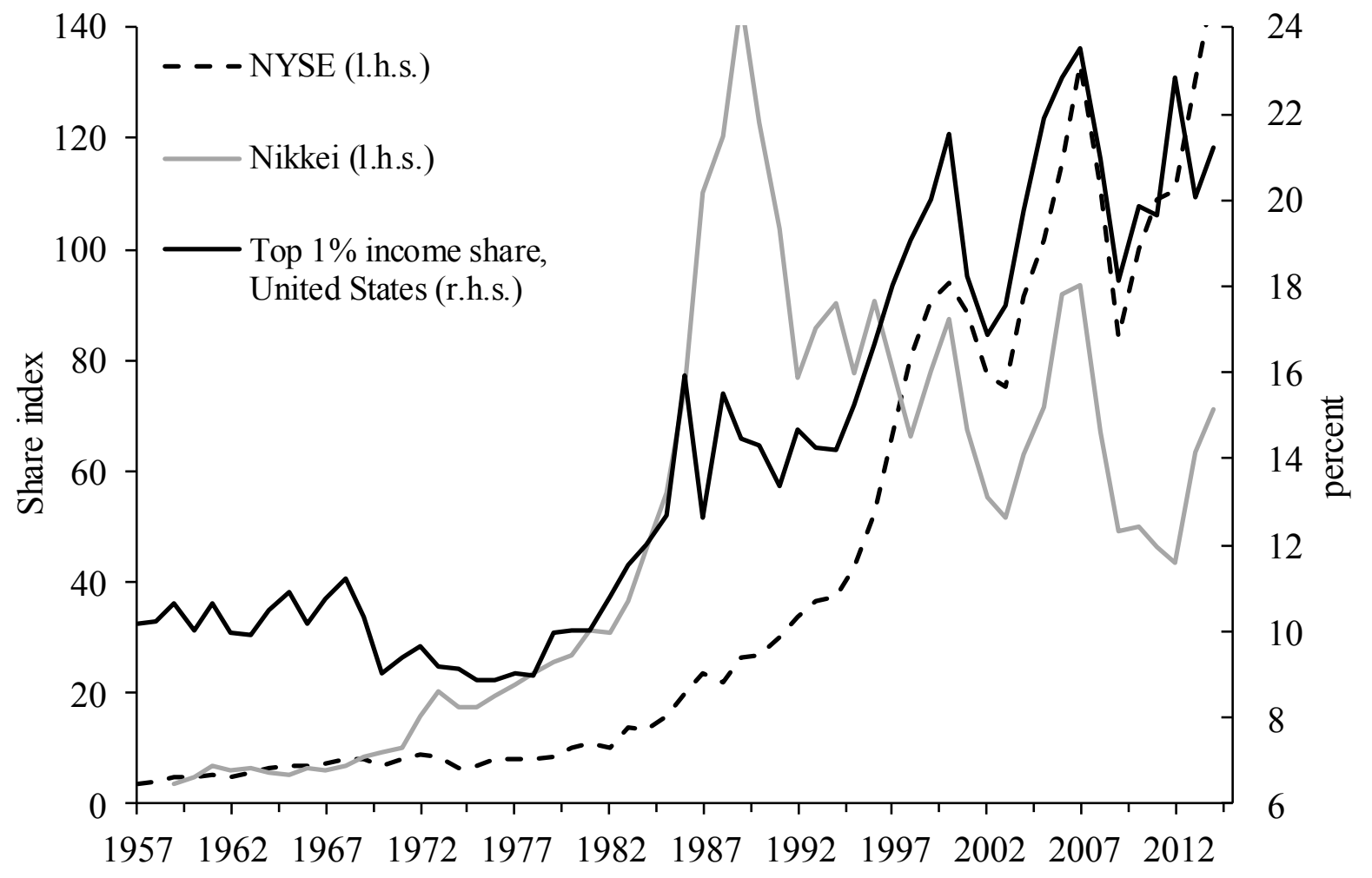

Source: OECD, Main Economic Indicators, The World Top Incomes Database. NYSE index: $2010=100$, Nikkei: $2010=50$. 
In contrast, returns of riskless assets, which are mainly held by middle and lower-income groups are depressed by the asymmetric monetary policy crisis management. ${ }^{32}$ Among other things, the returns on low-risk investments such as fixed-income savings and government bonds are lowered towards zero nominally and - given moderate inflation - into negative territory in real terms. Figure 15 shows the gradual decline of returns on low-risk investment classes such as government bonds and bank deposits in the large industrialized countries. This financial repression also changes the traditional banking business, as lending-deposit spreads are compressed and commercial banks are charged negative interest rates on their deposits at the central bank (Japan, euro area, Switzerland, etc.). ${ }^{33}$

\section{Figure 15: Interest Rates of Low-risk Assets in G3 Countries}

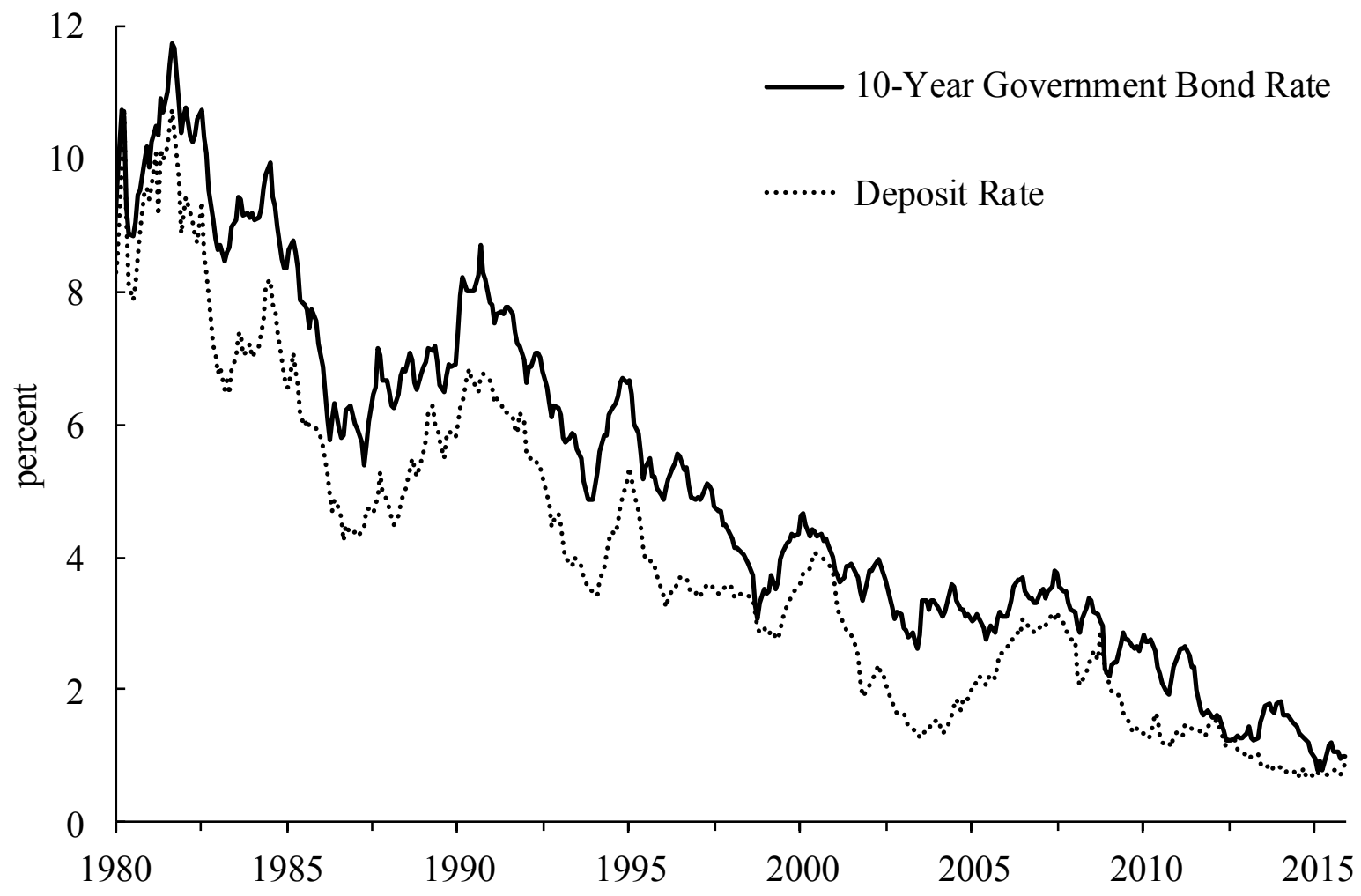

Sources: Thomson Reuters, IMF, German Bundesbank, arithmetic averages.

In addition to financial repression, real wage repression can occur when post-bubble crisis undermines the bargaining power of employees in the public and the private sector, while at the same time monetary policy crisis management leads to declining productivity gains, which are the basis for real wage increases. Financial crises (and growing public expenditure

\footnotetext{
32 Low and middle-income groups are assumed to hold more low-risk financial assets, because they perceive investments in the asset markets to be high-risk.

33 For more on financial repression see Hoffmann and Zemanek (2012).
} 
obligations triggered by exuberant boom phases in the financial markets) drive public debt upwards. ${ }^{34}$ During the course of crisis tax revenues structurally decline, while payment obligations can not be reduced at the same speed. To curtail the expenditure the public sector is forced to curtail wages. The signalling effects of public wage agreements as well as gloomy business expectations cause public austerity to be followed by wage moderation in the private sector. Wages are driven down especially in those segments of the labor market where qualification and bargaining power are low. Such nominal wage repression has been observed in most countries suffering from financial crises.

\section{Figure 16: Real Wage and Factor Income in Japan}

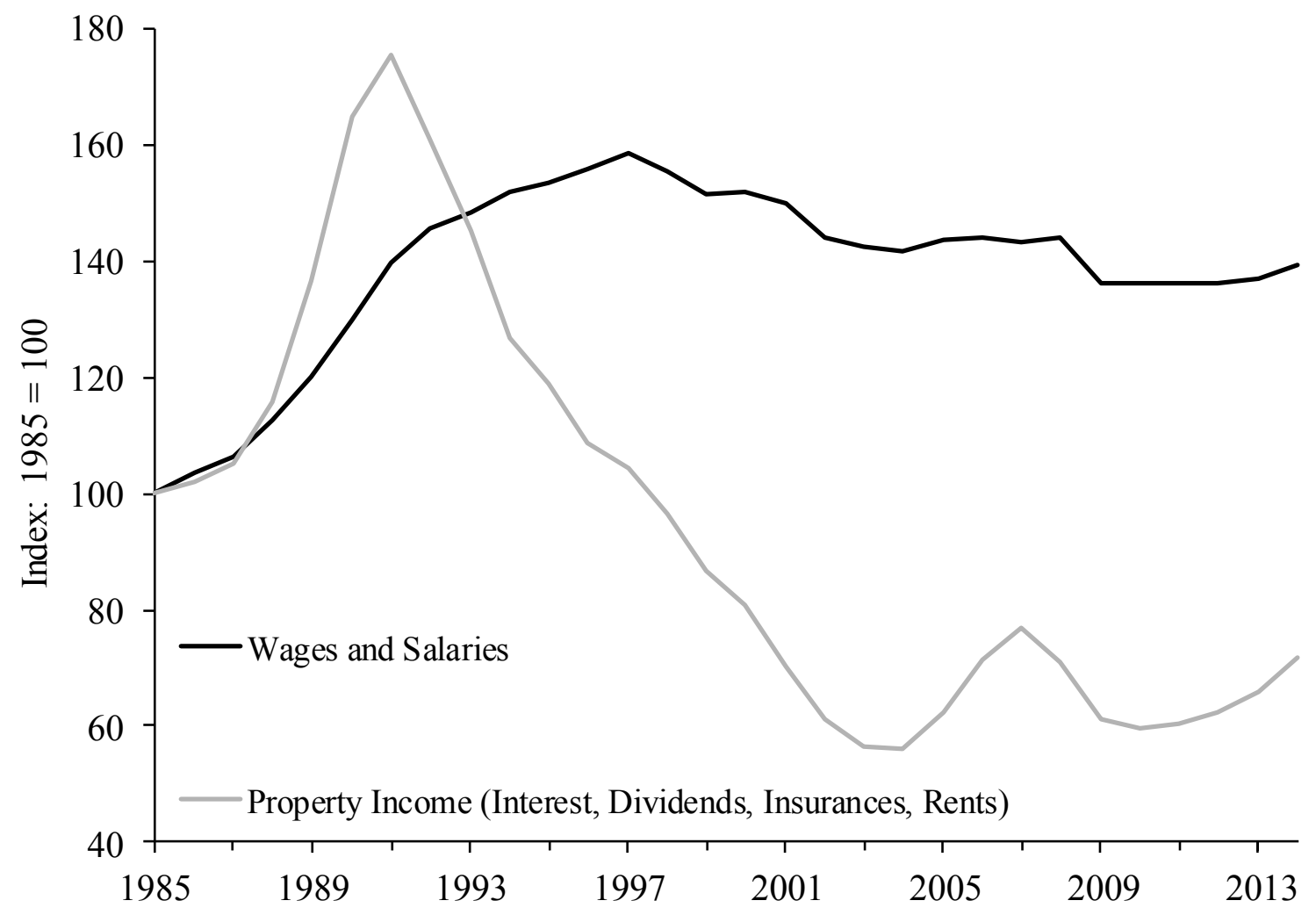

Source: Economic and Social Research Institute, Cabinet Office (Japan).

Usually young employees, who enter the labor markets, will be more exposed to nominal wage repression than older cohorts, whose contracts remain fixed. This is very clearly visible in Japan. As shown in Figure 16 the average real wage level has fallen steadily since the Japanese financial market crisis (1998). Given mainly stable prices, the decline of real wages is mainly achieved via declining average nominal wages. In Europe, too, nominal wage

34 As experience for instance in Greece, Portugal, Spain and Ireland prior to the crisis unsustainable financial market booms inflate tax revenues, which tempt governments to spend beyond their long-term means (see Eschenbach and Schuknecht 2004). 
repression in particular for the younger generation has increasingly become a reality since the outbreak of the European financial and debt crisis. ${ }^{35}$ Real wage repression cum financial repression can in turn be seen as important determinants of what leads to weak private demand of large proportions of the populations. If this is anticipated by enterprises, investment will remain sluggish. ${ }^{36}$ In a nutshell: the negative redistributive and real wage effects, which were traditionally widely ascribed to consumer price inflation, are now achieved indirectly - i.e. without consumer price inflation - via boom-and-crisis cycles in the financial markets.

\section{Persistence of Low Interest Rate Policies and Policy Implications}

An asymmetric monetary policy crisis management has self-reinforcing effects, if it encourages - directly and indirectly - an increase in national debt as observed in most industrialized countries. The higher are the levels of government debt, the higher is the pressure on central banks to keep key interest rates low and to continue purchases of government bonds via unconventional monetary policies. Otherwise, the interest rate burden of over-indebted governments would become unsustainable. The governments would be forced into politically unpopular structural reforms and spending cuts.

Furthermore, in the course of the monetary policy crisis management central banks tend to hold increasingly (potentially) bad assets in their balance sheets. As any monetary tightening would reduce the expected value of these assets, central banks would loose equity and therefore in the long term would necessitate recapitalization. As this would further undermine their independence, there is an incentive to continue the asymmetric monetary policy crisis management. Given the widely used inflation targets the persistence of unconventional monetary policies is technically possible, because monetary policy crisis management based on ultra- expansionary monetary policy has - due to Goodhart's law - no or a negative impact on consumer price inflation.

\footnotetext{
35 Germany is currently an exemption for two reasons. First, productivity increases, which have been pre-crisis exported to other European countries, are now partially repatriated, what has allowed for real wage increases since the outbreak of the crisis. Second, with the European Central Bank keeping monetary conditions very loose as crisis management for the Southern European crisis countries, a real estate bubble and export boom is fueled in Germany, which encourages real wages increases.

36 The negative demand effect of declining real incomes is partially offset by declining saving of the household sector, in particular of the younger generations.
} 
As described by Hayek $(1929,1937,1944)$ the Great Depression and the following stagnation of the 1930s were the outcome of too loose monetary policies, the resulting undue credit growth and intervention spirals in response to the crisis. In this paper it was shown that the current "secular stagnation" can be seen as the outcome - and not as the origin - of crisis management, which is based on excessive low-cost liquidity provision by central banks. To reverse the vicious circle of monetary policy crisis management and declining growth a timely exit from the ultra-low monetary policy is necessary to reconstitute the allocation and signalling function of the interest rate as well as the principle of liability in financial markets.

Despite negative growth effects in short-term (as non-productive investment has to be dismantled) by slowly, but irrevocably raising interest rates, growth could be restored. The incentives for financial market speculation would be reduced, as risk would become priced again based on market forces. The resulting cleansing process in financial markets would set free capital and labor for real investment, which was previously bound in sectors with low productivity. The increasing interest rates would provide an incentive for more household saving to finance growing investment. The marginal and average efficiency of investments would increase again. Aggregated saving and investments as well as innovation would be strengthened.

Growing debt-servicing costs would force governments to consolidate their spending by pushing forward structural reforms. Parts of the public economic activity would have to be privatized, which would contribute to an increasing average productivity of previously public investment. By substituting public consumption and investment by private investment, the average efficiency of investment would increase. Fiscal consolidation combined with rising interest rates would encourage banks to restore their traditional business model. The banking sector would return to its very task to finance investment projects with the highest expected returns (instead of buying government bonds). This would lead to pressure on enterprises to come up with innovative investment projects. A higher degree of X-Efficiency would be reached.

Productivity gains would allow real wages to grow again. This would be even more the case for the middle and low income classes if the adverse redistribution effects of boom and bust in financial markets would be eliminated. A growing purchasing power of broad parts of the 
middle and lower income classes would help to fully use the newly created capacities. Growing income levels would contribute to higher tax revenues for the state, which could be used to reduce public debt. The political pressure towards regulation, price and rent controls and redistribution of wealth etc. would be eased. A higher degree of economic freedom would help to create sustainable growth and to secure welfare for all parts of the society. This would all help to contain political polarization, which has been favored by the increasing income inequalities.

\section{References}

Adrian, Tobias / Shin, Hyun Song (2008): Liquidity, Monetary Policy and Financial Cycles. Current Issues in Economics and Finance 14, 1.

Akerlof, George (1970): The Market for Lemons: Quality Uncertainty and the Market Mechanism. Quarterly Journal of Economics 84, 3, 488-500.

Barro, Robert / Gordon, David (1983): A Positive Theory of Monetary Policy in a Natural Rate Model. Journal of Political Economy 91, 4, 589-610.

Barnett, Alina / Chiu, Adrian / Franklin, Jeremy / Sebastiá-Barriel, María (2014): The Productivity Puzzle: a Firm-Level Investigation into Employment Behaviour and Ressource Allocation over the Crisis. Bank of England Working Paper 495.

Blinder, Alan / Reis, Ricardo (2005): Understanding the Greenspan Standard. Princeton University Department of Economics Working Papers 88.

Bernanke, Ben (1995): The Macroeconomics of the Great Depression: A Comparative Approach. Journal of Money, Credit, and Banking 27, 1, 1-28.

Bernanke, Ben (2000): Japanese Monetary Policy. A Case of Self-Induced Paralysis? In: Mikitani, Ryoichi / Posen, Adam (eds.): Japan's Financial Crisis and Its Parallels to U.S. Experience, Institute for International Economics, Washington D.C., 149-166.

Bernanke, Ben (2002): Remarks by Governor Ben S. Bernanke at the Conference to Honor Milton Friedman, University of Chicago, Chicago, Illinois, November 8, 2002.

Bernanke, Ben (2005): The Global Saving Glut and the U.S. Current Account Deficit. Remarks at the Sandridge Lecture, Virginia Association of Economists, Richmond, Virginia.

Borio, Claudio (2014): The Financial Cycle and Macroeconomics: What Have We Learnt? Journal of Banking and Finance 45, 182-198.

Borio, Claudio / Kharroubi, Enisse / Upper, Christian / Zampolli, Fabrizio (2016): Labour Reallocation and Productivity Dynamics: Financial Causes, Real Consequences. BIS 
Working Papers 534.

Brunnermeier, Markus / Schnabel, Isabel (2014): Bubbles and Central Banks: Historical Perspectives. Mimeo.

Caballero, Ricardo / Hoshi, Takeo, / Kashyap, Anil (2008): Zombie Lending and Depressed Restructuring in Japan. American Economic Review 98, 5, 1943-1977.

Cantillon, Richard (1931): Abhandlung über die Natur des Handels im allgemeinen, Jena.

Cardarelli, Roberto / Lusinyan, Lusine (2015): U.S. Total Factor Productivity Slowdown: Evidence from the U.S.. IMF Working Paper 15/116.

De Grauwe, Paul (2011): Monetary Policy and Animal Spirits. Economic Theory 47, 2-3, 423-457.

De Haan, Jacob / Sturm, Jan Egbert (2016): Finance and Income Inequality: A Review and New Evidence. CESifo Working Papers 6079.

Dell'Arricia, Giovanni / Igan, Deniz / Laeven, Luc / Tong, Hui / Bakker, Bas / Vandenbussche, Jérôme (2012): Policies for Macrofinancial Stability: How to Deal with Credit Booms. IMF Staff Discussion Note SDN/12/06.

Disyatat, Piti (2008): Monetary Policy Implementation: Misconceptions and their Consequences. BIS Working Paper 269.

Eschenbach, Felix / Schuknecht, Ludger (2004): Budgetary Risks from Real Estate and Stock Markets. Economic Policy 19, 39, 313-346.

Friedman, Milton (1970): Counter-Revolution in Monetary Theory. Wincott Memorial Lecture, Institute of Economic Affairs Occasional Paper 33.

Friedman, Milton / Schwartz, Anna (1953): A Monetary History of the United States, 18671960, Princeton.

Gertler, Pavel / Hofmann, Boris (2016): Monetary Facts Revisited. BIS Working Papers 566.

Goodhart, Charles (1975): Problems of Monetary Management: The UK Experience. Paper Presented for the Conference in Monetary Economics, Reserve Bank of Australia.

Gopinath, Gita / Kalemli-Özkan, Şebnem / Karabarbounis, Loukas / Villegas-Sanchez, Carolina (2015): Capital Allocation and Productivity in South Europe. Mimeo.

Gordon, Robert (2012): Is U.S. Economic Growth Over? Faltering Innovation Confronts the Six Headwinds. NBER Working Paper 18315.

Hayek, Friedrich August von (1929): Geldtheorie und Konjunkturtheorie, Salzburg, Philosophia Verlag.

Hayek, Friedrich August von (1931): Prices and Production. New York, August M. Kelly Publishers. 
Hayek, Friedrich August von (1937): Monetary Nationalism and International Stability, Augustus Kelley Publishers, Fairfield, New Jersey.

Hayek, Friedrich August von (1944): The Road to Serfdom, Routledge, London.

Hayek, Friedrich August von (1968): Der Wettbewerb als Entdeckungsverfahren. In: Internationales Institut „Österreichische Schule der Nationalökonomie" (Hrsg.): Die Österreichische Schule der Nationalökonomie. Texte - Band II von Hayek bis White. Wien: Manz'sche Verlags- und Universitätsbuchhandlung, 119-137.

Hoffmann, Andreas / Schnabl, Gunther (2008): Monetary Policy, Vagabonding Liquidity and Bursting Bubbles in New and Emerging Markets - An Overinvestment View. The World Economy 31, 1226-1252.

Hoffmann, Andreas / Schnabl, Gunther (2011): A Vicious Cycle of Manias, Crises and Asymmetric Policy Responses - An Overinvestment View. The World Economy 34, 382403.

Hoffmann, Andreas / Schnabl, Gunther (2016a): Monetary Policy in Large Industrialized Countries, Emerging Market Credit Cycles, and Feedback Effects. Journal of Policy Modeling 38, 3, 1-19.

Hoffmann, Andreas / Schnabl, Gunther (2016b): The Adverse Effects of Ultra-Loose Monetary Policies on Investment, Growth and Income Distribution. Together with Andreas Hoffmann. Cato Journal 36, 3, 449-484.

Hoffmann, Andreas / Zemanek, Holger (2012): Financial Repression and Debt Liquidation in the US and the Euro Area. Intereconomics: Review of European Economic Policy 47, 6, 344-351.

Jorda, Oskar / Schularick, Moritz / Taylor Alan (2015): Betting the House. Journal of International Economics 96, 1, 2-18.

Keynes, John Maynard (1936): The General Theory of Employment, Interest, and Money, Cambridge, Macmillan Cambridge University Press.

Koo, Richard (2003): Balance Sheet Recession: Japan's Struggle with Uncharted Economics and its Global Implications, Wiley and Sons.

Kornai, János (1986): The Soft Budget Constraint. Kyklos 39 1, 3-30.

Kydland, Finn / Prescott, Edward (1977): Rules Rather than Discretion: The Inconsistency of Optimal Plans. Journal of Political Economy 85, 473-490.

Leibenstein, Harvey (1966): Allocative Efficiency vs. X-Efficiency. American Economic Review 56, 3, 392-415.

Laubach, Thomas / Williams, John (2015): Measuring the Natural Rate of Interest Redux. Federal Reserve Bank of San Francisco Working Paper 2015-16. 
Lucas, Robert (1976). Econometric Policy Evaluation: A Critique. Carnegie-Rochester Conference Series on Public Policy 1, 19-46.

McKinnon, Ronald (1973): Money and Capital in Economic Development. Washington: The Brookings Institution.

McKinnon, Ronald (2012): Zero Interest Rates in the United States Provoke World Monetary Instability and Constrict the U.S. Economy. SIEPR Policy Brief, Stanford, August 2012.

Mises, Ludwig von (1912): Die Theorie des Geldes und der Umlaufmittel, Duncker und Humblot, Leipzig.

Mises, Ludwig von (1949): Human Action, $4^{\text {th }}$ ed., FEE, New York.

Peek, Joe / Rosengren, Eric (2005): Unnatural Selection: Perverse Incentives and the Misallocation of Credit in Japan. American Economic Review 95, 4, 1144-1166.

Posen, Adam (2000): The Political Economy of Deflationary Monetary Policy. In: Mikitani, Ryoichi / Posen, Adam (eds.): Japan's Financial Crisis and Its Parallels to U.S. Experience, Institute for International Economics, Washington D.C., 194-208.

Quian, Yingyi / Xu, Chenggang (1998): Innovation and Bureaucracy under Soft and Hard Budget Constraints. Review of Economic Studies 65, 1, 151-164.

Reinhart, Carmen / Reinhart, Vincent (2010): After the Fall. NBER Working Paper 16334.

Schnabl, Gunther / Wollmershäuser, Timo (2013): Fiscal Divergence and Current Account Imbalances in Europe. CESifo Working Paper 4108 (2013).

Schumpeter, Joseph (1912): The Theory of Economic Development, Cambridge, Massachussetts.

Sekine, Toshitaka / Kobayashi, Keiichiro / Saita, Yumi (2003): Forbearance Lending: The Case of Japanese Firms. Bank of Japan Institute for Monetary and Economic Studies 21, 2, 69-92.

Shaw, Edward (1973): Financial Deepening in Economic Development. New York: Oxford University Press.

Solow, Robert (1956): A Contribution to the Theory of Economic Growth. Quarterly Journal of Economics 70, 1, 65-94.

Solow, Robert (1957): Technical Change and the Aggregate Production Function. Review of Economics and Statistics 39, 2, 312-320.

Summers, Larry (2014): U.S. Economic Prospects: Secular Stagnation, Hysteresis, and the Zero Lower Bound. Business Economics 49, 2, 65-73.

Swan, Trevor (1956): Economic Growth and Capital Accumulation. Economic Record 32, 2, 334-361. 
Taylor, John (1993): Discretion versus Policy Rules in Practice. Carnegie-Rochester Conference Series on Public Policy 39, 195-214.

Taylor, John (2007): Housing and Monetary Policy, NBER Working Paper 13682.

Yoshino, Naoyuki / Mizoguchi, Tetsuro (2010): The Role of Public Works in the Political Business Cycle and the Instability of the Budget Deficits in Japan. Asian Economic Papers 9, 1, 94-112.

von Weizsäcker, Christian (2014): Public Debt and Price Stability. German Economic Review $15,1,42-61$

Wicksell, Knut (1898 [2005]): Geldzins und Güterpreise, FinanzBuch Verlag, München.

Wicksell, Knut (1936): Interest and Prices, London: Macmillan, 1936). Translation of 1898 edition by R. F. Kahn.

Woodford, Michael (2003): Interest and Prices. Foundations of a Theory of Monetary Policy, Princeton University Press, Princeton. 